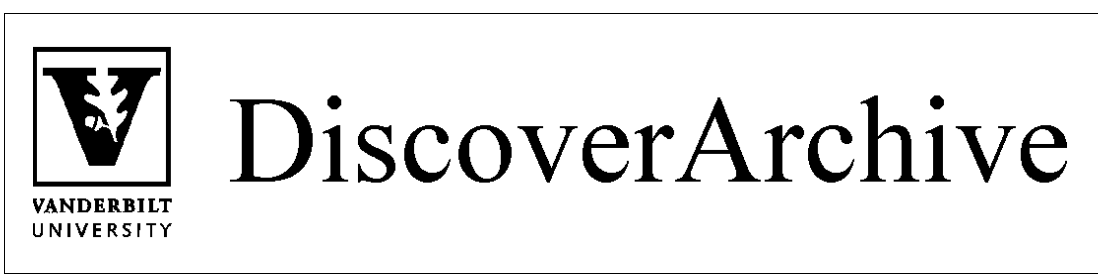

Retrieved from DiscoverArchive,

Vanderbilt University's Institutional Repository

This work was originally published in

19 Sup. Ct. Econ. Rev. 1032011

(C) 2011 by The University of Chicago. All rights reserved. 


\title{
Economics, Behavioral Biology, and Law
}

\author{
Owen D. Jones, ${ }^{*}$ Erin O'Hara O'Connor, ${ }^{*}$ * \\ and Jeffrey Evans Stake***
}

This article compares the relevance to law of two unexpectedly similar fields: economics and behavioral biology. It first examines the assumptions, core concepts, methodological tenets, and emphases of the two fields. It then compares the interdisciplinary fields of law and economics, on one hand, with law and behavioral biology, on the other-highlighting not only important similarities but also important differences. The article subsequently explores ways that biological perspectives on human behavior may, among other things, improve economic models and the behavioral insights they generate. The article concludes that although there are important differences between the two fields, the overlaps between economics and biology warrant even greater congress between these two disciplines, and expanded exchange between the legal thinkers interested in each of them.

* New York Alumni Chancellor's Chair in Law \& Professor of Biological Sciences, Vanderbilt University; Director, MacArthur Foundation Law and Neuroscience Project. The authors thank Bart Du Laing, Richard Epstein, Timothy Goldsmith, Oliver Goodenough, David Herring, Greg La Blanc, Henry Manne, John Monahan, Robert Rasmussen, Ed Rubin, Paul Rubin, Paige Skiba, Todd Zywicki and several anonymous reviewers for helpful comments. We are grateful for the research assistance of Susan Eisenberg and Alex Cao.

** FedEx Research Professor of Law, Vanderbilt University.

$\star \star \star$ Robert A. Lucas Chair of Law, Indiana University Maurer School of Law. 


\section{IN T R O D UCTION}

With the decline of law as an autonomous discipline ${ }^{1}$ legal scholars have long sought ways to improve law by integrating insights from other fields. For the most part, these efforts have mined the social sciences, such as sociology, political science, and traditional psychology. More recently, however, scholars have turned to the natural sciences, including behavioral biology and neuroscience, in an effort to learn more about the multiple causal influences on human behaviors relevant to law.

Because law and economics is arguably the most successful of the "law and" intersections, it is inevitable that other interdisciplinary efforts will be compared to it. For example, several years ago John Monahan posed the question, in an article by this title, "Could "Law and Evolution" be the Next "Law and Economics"? ${ }^{2} \mathrm{We}$ think the question warrants an extended examination and explicit answer. ${ }^{3}$ Each of us has worked for some years at the intersection of law and biology, ${ }^{4}$ at the intersection of law and economics, ${ }^{5}$ or

\footnotetext{
${ }^{1}$ Richard A. Posner, The Decline of Law as an Autonomous Discipline: 1962-1987, 100 Harv L Rev 761 (1987).

"John Monahan, Could "Law and Evolution" be the Next "Law and Economics"?, 8 Va J Soc Pol'y \& L 123 (2000).

${ }^{3}$ For a recent article exploring some of the "deeply resonant" thinking between law and biology and law and economics, see Morris B. Hoffman, Law and Biology, 8 J Phil, Sci \& L (2008). For additional discussion of Monahan's article, see David J. Herring, Legal Scholarship, Humility, and the Scientific Method, 25 Q L Rev 867 (2007).

${ }^{4}$ See, for example, Owen D. Jones \& Timothy H. Goldsmith, Law and Behavioral Biology, 104 Colum L Rev 405 (2005); Paul Robinson, Robert Kurzban \& Owen D. Jones, The Origins of Shared Intuitions of Justice, 60 Vanderbilt L Rev 1633 (2007); Erin Ann O'Hara, How Neuroscience Might Advance the Law, 359 Phil Trans R Soc Lond B 1677 (2004), reprinted as chapter 2 in Semir Zeki and Oliver Goodenough, eds, Law $Æ$ the Brain 21 (Oxford 2006); Erin Ann O'Hara, Brain Plasticity and Spanish Moss in Biolegal Analysis, 53 Fla L Rev 905 (2001); Jeffrey Evans Stake, The Property 'Instinct', 359 Phil Trans R Soc Lond B 1763 (2004), reprinted as chapter 10 in Law せ) the Brain 185; Jeffrey Evans Stake, Pushing Evolutionary Analysis of Law, 53 Fla L $\operatorname{Rev} 875$ (2001).

Of course, we are not alone in this. Many have made, and continue to make, significant contributions to each of these fields. Jones maintains a bibliography of many scholarly works at the intersection of Law and Biology on the website of The Society for Evolutionary Analysis in Law (SEAL), online at http://www.sealsite.org.

${ }^{5}$ See, for example, Erin Ann O'Hara, The Economics of Conflict of Laws $(2$ volume edited work, Edward Elgar 2007); Erin Ann O'Hara, Economics, Public Choice, and the Perennial Conflict of Laws, 90 Geo L J 941 (2002); Erin Ann O'Hara \& Larry E. Ribstein, From Politics to Efficiency in Choice of Law, 67 U Chi L Rev 1151 (2000); William H. Allen \& Erin A. O'Hara, Second Generation Law and Economics of Conflict of Laws: Baxter's Comparative Impairment and Beyond, 51 Stan L Rev 1011 (1999); Erin Ann O'Hara \& Larry E. Ribstein, Choice of Law/Conflict of Laws, in Gerritt de Geest,
} 
both. ${ }^{6}$ Perhaps unsurprisingly, we see similarities and differences in the two fields that suggest that the answer to Monahan's question is: in some ways yes, and in some ways no.

We structure our approach as follows. Part II provides background information useful to the discussion in the remainder of the article. Part III compares microeconomics ${ }^{7}$ and biology generally. Part IV then compares law and economics, on one hand, with law and behavioral biology, ${ }^{8}$ on the other. These latter two Parts very briefly compare the assumptions, core concepts, methodological tenets,

ed, Ghent Encyclopedia of Law and Economics (Edward Elgar 2000); Erin Ann O'Hara \& Francesco Parisi, Conflict of Laws, in The New Palgrave Dictionary of Economics and the Law 387-96 (Macmillan 1998); Erin Ann O'Hara \& William Dougan, Redistribution Through Discriminatory Taxes: A Contractarian Explanation of the Role of the Courts, 6 Geo Mason L Rev 869 (1998); Erin Ann O'Hara \& Richard S. Murphy, Mistake of Federal Criminal Law: A Study of Coalitions and Costly Information, $5 \mathrm{~S}$ Ct Econ Rev 217 (1997); Erin Ann O'Hara, Social Constraint or Implicit Collusion?: Toward A Game Theoretic Analysis of Stare Decisis, 24 Seton Hall L Rev 736 (1993); Jeffrey E. Stake, Inheritance Law and Land Use Doctrines, 2 Peter Newman, ed, The New Palgrave Dictionary of Economics and the Law 311-21, 437-46 (Macmillan 1998); Jeffrey Evans Stake, The Uneasy Case for Adverse Possession, 89 Geo L J 2419 (2001). In addition, Stake co-founded the Midwest Law and Economics Association with Thomas Ulen and Kenneth Dau-Schmidt.

${ }^{6}$ Owen D. Jones, Time-Shifted Rationality and the Law of Law's Leverage: Behavioral Economics Meets Behavioral Biology, 95 NW U L Rev 1141 (2001); Owen D. Jones \& Sarah F. Brosnan, Law, Biology, and Property: A New Theory of the Endowment Effect, 49 Wm \& Mary L Rev 1935 (2008); Erin Ann O'Hara \& Douglas Yarn, On Apology and Consilience, 77 Wash L Rev 1121 (2002); Jeffrey Evans Stake, Darwin, Donations, and the Illusion of Dead Hand Control, 64 Tulane L Rev 705-81 (1990); Jeffrey Evans Stake, Evolution of Rules in a Common Law System: Differential Litigation of the Fee Tail and Other Perpetuities, chapter 17 in Paul H. Rubin, ed, The Evolution of Efficient Common Law (Edward Elgar 2007), volume 3 in series Economic Approaches to Law (Richard A. Posner and Francesco Parisi, eds). In addition, each of us is a founding officer of the Society for Evolutionary Analysis in Law-the website is available online at http://www.sealsite.org.

${ }^{7}$ The economics used to enrich legal studies has been almost entirely limited to microeconomics. Because the movement is called "law and economics" and because "economics" is more compact than "microeconomics", we shall use the term "economics" even though "microeconomics" would be more accurate.

${ }^{8}$ Alternatively referred to as "law and biology" (see, for example, programs of the Gruter Institute for Law and Behavioral Research), "evolutionary analysis in law" (see, for example, Owen D. Jones, Evolutionary Analysis in Law: An Introduction and Application to Child Abuse, 75 NC L Rev 1117 (1997) and "law and evolution" (see, for example, Monahan (cited in note 2)). A further note on terminology: Behavioral biology comprises a wide variety of subdisciplines. Unless otherwise noted, the term as used here will refer to behavioral biology applied to the human context, which has overlaps with evolutionary psychology, evolutionary anthropology, behavioral ecology, sociobiology, Darwinian medicine, behavioral genetics, and the like. We exclude, from this discussion, several other important subfields of behavioral biology such as psychopharmacology. 
and emphases of the fields of economics and behavioral biology, and then explore the influences of these and other similarities and differences on the development of the applied fields of law and economics and law and behavioral biology. Part V then further explores some ways in which biological perspectives can provide useful insights into human behavior by, among other things, improving economic models and the behavioral insights they generate. Finally, it provides advice to law and biology scholars seeking to avoid some of the criticisms directed at law and economics.

Underlying our discussion below are two convictions. First, we believe that a deeper, more accurate, and biologically informed understanding of the relationships between biology, evolution, and human behavior might help legal thinkers pursue policy goals more efficiently and effectively than they do at present. Law makers need sound models of when, why, and how people behave. And behavior is - though the product of many influences-a biological phenomenon. It emerges in non-random ways from a corporeal brain that is flexible, subtle, plastic, and often self-conscious, on one hand, while being both anatomically and functionally specialized, on the other. Second, just as with law and economics generally-and with particular acknowledgment of the history of political mis-invocation of biology - potentially useful insights must be carefully mined and cautiously deployed.

\section{CONTEXT}

This Part does two things. It addresses why behavioral biology and economics probably have more in common than do economics and any of the other interdisciplinary subfields to which it is often compared. And it provides a very brief overview of the relationship between economics and behavioral biology. Together, these provide background useful to the remainder of the article.

Biology and economics share, as a central concern, the effects of resource scarcity on behavior. ${ }^{9}$ Not surprisingly, then, the overlaps and interactions between economics and biology are long-standing

9 The population of every species can increase indefinitely in number, unless checked by some scarcity—of food, space, mates, or the like. See Mark Ridley, Evolution 63 (3d ed, Blackwell Scientific 1993). In animals, this creates selection pressures that favor characteristics, including behavioral predispositions, that can aid survival and reproduction in conditions of scarcity. See generally, John Alcock, Animal Behavior: An Evolutionary Approach (8th ed., Sinauer Associates 2005). And economics has been called "the study of the allocation of scarce means to satisfy competing ends." Gary S. Becker, Economic Theory 1 (Knopf 1971). 
and extensive. Perhaps the most famous and explicit interaction, however, was the influence of political economist Thomas Malthus on biologist Charles Darwin.

Malthus' work pointed out that geometrically increasing populations could outgrow food supplies, leading to scarcity and famine. ${ }^{10}$ Darwin read Malthus at a time (the year 1838, according to Darwin's 1876 autobiography ${ }^{11}$ ) when he was keenly prepared to appreciate and explore the consequences of this insight. And it helped provide the tool he needed to identify, name, and describe "natural selection"12 as a major force in evolution. ${ }^{13}$ Darwin realized that when population growth can outstrip resources, and when more offspring are produced than can survive to reproduce themselves, any heritable variations in the traits of offspring that increase their chances of survival and eventual reproduction (compared to the chances of their contemporaries) will tend to appear in increasingly large percentages in subsequent generations. This means that individuals within a species can, over generations, come to look as if their traits were "designed" for efficient operation within the ecological niches they inhabit.

Importantly, natural selection affects not only anatomical traits, but associated behavioral predispositions (tracing to anatomical traits of the nervous system) as well. From this perspective, animals can be considered choice machines-since the best anatomy in the world won't help if you don't deploy it in useful ways, at suitable times. At any given moment, the choice to forage, flee, scratch,

${ }^{10}$ Thomas Malthus, Essay on the Principle of Population (Printed for J. Johnson 1798).

${ }^{11}$ Appearing as Charles Darwin, Autobiography, in F. Darwin, ed, The Life and Letters of Charles Darwin 68 (Murray1887), which contained the following passage:

In October 1838, that is, fifteen months after I had begun my systematic enquiry, I happened to read for amusement 'Malthus on Population,' and being well prepared to appreciate the struggle for existence which everywhere goes on from long-continued observation of the habits of animals and plants, it at once struck me that under these circumstances favourable variations would tend to be preserved, and unfavourable ones to be destroyed. The results of this would be the formation of new species. Here, then I had at last got a theory by which to work. ...

Some trace the influence of economics on Darwin's work back even further, to encountering Adam Smith's work in the early 1830s. See, for example, Stephen Jay Gould, The Structure of Evolutionary Theory 121-25 (Belknap 2002) (citing S.S. Schweber, The Origin of the Origin Revisitied, 10 J History Biol 229 (1977)).

${ }^{12}$ Natural selection describes the result of systems combining reproduction, heritable traits, variations in those traits; and differential reproduction as a function of variation in heritable traits. See Ridley, at 63 (cited in note 12).

${ }^{13}$ Charles Darwin, The Origin of Species (Murray 1859). 
drink, fight, sleep, seek a mate, strengthen cooperative alliances, or travel to another location may yield benefits, but at the cost of both invested energy and foregone benefits from alternative activities. Those organisms predisposed (typically though not exclusively through natural selection) to those behaviors (from among all possible behaviors) that increased the probabilities of survival and eventual reproduction more than do alternative behaviors "chosen" by other members of the species left more offspring, many of which would share these behavioral inclinations. Such inclinations are frequently, of course, highly context-specific and condition-dependent. That is, evolutionary processes can equip an organism with "if-then" algorithms (often hierarchically ranked ${ }^{14}$ ) such that: if encountering environmental condition $\mathrm{A}$, increase the probability of behaving in way $\mathrm{Y}$; but if encountering condition $\mathrm{B}$, increase the probability of behaving in way Z. And because the field of economics is largely dedicated to the study of choice given particular costs and benefits, biologists naturally gravitated toward economic tools.

Important intellectual insights have flowed in the other direction as well. For example, in 1898, the economist Thorstein Veblen famously asked, in the title of an article, "Why is economics not an evolutionary science?"15 And by the 1920's, economist Alfred Lord Marshall argued that "[economics] is a branch of biology broadly interpreted." 16

Within a few decades thereafter, economists Milton Friedman and Armen Alchian had constructed powerful arguments for positive economic modeling of business behavior on the foundation of Darwin's basic insight. ${ }^{17}$ Friedman and Alchian invoked Darwinian analysis (by analogy) to argue that businesses that make a profit will survive in the market and those that do not will fail. When businesses fail, the labor and capital they employed are freed up for other uses, of which some will turn out to be more productive and others will, again, fail.

${ }^{14}$ A good example of such hierarchical algorithms is the mating behavior of the male scorpionfly, which has a preferred behavior, a backup behavior, and a backupbackup behavior, which it switches among in sequence as circumstances change. See Randy Thornhill, Rape in Panorpa Scorpionflies and a General Rape Hypothesis, 28 Animal Behav 52 (1980).

${ }^{15}$ Thorstein Veblen, Why Is Economics Not An Evolutionary Science?, Q J Econ 373 (1898).

${ }_{16}$ Alfred Lord Marshall, Principles of Economics Appdx C, 722 (Macmillan 1910, $6^{\text {th }}$ ed.).

${ }^{17}$ Milton Friedman, The Methodology of Positive Economics, in Milton Friedman, ed, Essays in Positive Economics 35 (Chicago 1953); Armen A. Alchian, Uncertainty, Evolution, and Economic Theory, $58 \mathrm{~J}$ Pol Econ 211 (1950). 
Thus, the market culls out unsuccessful businesses, those that employ resources inefficiently, leaving those that make more of resources. While the environment selects for business success, the evolutionary process is very often facilitated by business managers who consciously and unconsciously copy the operations of successful businesses. The copies are often imperfect, both by design and inadvertence, and the resulting variations are subjected to selection on the criterion of efficiency. To quote Alchian, the economist's "analytical framework . . . is closely akin to the theory of biological evolution. The economic counterparts of genetic heredity, mutations, and natural selection are imitation, innovation, and positive profits." ${ }^{\prime 18}$

Friedman and Alchian contended that, because Darwinian selection (or "adoption" to use Alchian's word) is at work, economists need not worry about whether business managers make decisions by knowingly invoking the concepts used by economists. The behavior of firms can be explained and predicted without examining the thoughts going through the heads of the managers.

This shared perspective of an environment selecting among variations led both economics and biology away from top-down explanations and toward bottom-up understandings of complexity. ${ }^{19}$ Extremely complex biological organisms exist not because they were designed by a creator attending to every detail but because wasteful characteristics are typically selected out of the countless random variations by the competition for resources. Likewise, extremely complex and coordinated economic markets can arise without the need for design by an all-knowing designer, merely by the competitive actions of individual, atomistic actors.

The decades since these early interactions have been characterized by the convergence of the intellectual tools used in biology and economics, as indicated by the influential scholarship both from a number of biologists influenced by economics (such as Robert Trivers, Maynard Smith, and Michael Ghiselin ${ }^{20}$ ) and from a number of

${ }^{18}$ Alchian, Uncertainty at 220 (cited in note 17).

${ }^{19} \mathrm{~A}$ brief overview of some related history appears in the essay of Peter A. Corning, Evolutionary Economics: Metaphor or Unifying Paradigm?, 18 J of Soc \& Evo Systems 421 (1996) (reviewing two books on the intersection of economics and evolutionary biology).

${ }^{20}$ See, for example, Robert L. Trivers, Parent-Offspring Conflict, 14 Amer Zool 249 (1974); John Maynard Smith, Evolution and the Theory of Games (Cambridge 1982); Michael T. Ghiselin, Principles and Prospects for General Economy, in Gerard Radnitzky \& Peter Bernholz, eds, Economic Imperialism: The Economic Approach Applied Outside the Field of Economics (Paragon House 1987). 
economists influenced by biology (such as Gary Becker, Jack Hirshleifer, Paul Rubin, Robert Frank, and Herbert Gintis ${ }^{21}$ ). For instance, in developing theories of optimal foraging and ritual combat, John Maynard Smith and George Price borrowed heavily from economic game theory and built on it, and then economists borrowed back, incorporating evolutionary game theory. ${ }^{22}$ And in recent years, economists and biologists have moved beyond borrowing from each other to working together, yielding advances on both empirical and theoretical fronts. ${ }^{23}$

The combined influence of biologists thinking economically and economists thinking biologically has lead to interesting and increasing interdisciplinary endeavors, evident from even a casual glance through economic and biological literatures. ${ }^{24}$ To give just a brief flavor of this:

${ }^{21}$ See, for example, Gary S. Becker, Altruism, Egoism, and Genetic Fitness: Economics and Sociobiology, $14 \mathrm{~J}$ Econ Lit 817 (1976); Jack Hirshleifer, Economics From A Biological Viewpoint, 20 J L \& Econ 1 (1977); Paul H. Rubin, Why is the Common Law Efficient?, 6 J Leg Stud 51 (1977) reprinted in Paul Rubin, ed, The Evolution of Efficient Common Law (Edward Elgar 2007); Robert Frank, Cooperation through Emotional Commitment, in Randolph Nesse, ed, Evolution and the Capacity for Commitment (Russell Sage Foundation 2001); Herbert Gintis, Game Theory Evolving (Princeton 2000).

${ }^{22}$ Peter Hammerstein \& Edward H. Hagen, The Second Wave Of Evolutionary Economics In Biology, 20 Trends in Ecology \& Evolution 604, 604 (2005). As Mahoney and Sanchirico put it:

Evolutionary game theory grew out of an intellectual volley between theoretical biology and game theory. The history begins with an attempt by theoretical biologists John Maynard Smith and George Price to understand ritual combat within species. Unsatisfied with explanations provided by conventional evolutionary theory, Maynard Smith and Price borrowed ideas from game theory, modifying the interpretation of key constructs to fit the contours of animal evolution. A decade or so later, many game theorists became dissatisfied with the foundational assumptions underlying Nash equilibrium, in particular the requisite assumption that players somehow know what their opponents are going to do. In seeking explanations for the genesis of this common understanding of strategic intent, game theorists turned to the concepts of learning and evolution, thus borrowing back Maynard Smith and Price's earlier adaptation of the game form to animal evolution. The result is the field of evolutionary game theory.

Paul G. Mahoney \& Chris W. Sanchirico, Competing Norms and Social Evolution: Is the Fittest Norm Efficient?, 149 U Pa L Rev 2027, 2039-40 (2001).

${ }^{23}$ Id at 604.

${ }^{24}$ For one view of these interactions, see Geoffrey M. Hodgson, Taxonomizing the Relationship Between Biology and Economics: A Very Long Engagement, 9 J Bioecon $169(2007)$. 
- Recent years have seen the emergence of hybrid terms such as "bioeconomics"25 (sometimes "bionomics"26), "evolutionary economics, ${ }^{127}$ and "neuroeconomics." 28

${ }^{25}$ See, for example, Michael T. Ghiselin, A Bibliography for Bioeconomics, $2 \mathrm{~J}$ Bioecon 233 (2000); Ulrich Witt, Bioeconomics as Economics from a Darwinian Perspective, 1 J Bioecon 19 (1999); Janet Tai Landa \& Michael T. Ghiselin, The Emerging Discipline Of Bioeconomics: Aims And Scope Of The Journal Of Bioeconomics, $1 \mathrm{~J}$ Bioecon 5 (2004); Michael T. Ghiselin, Biology, Economics, and Bioeconomics, in Universal Economics 71 (Paragon House 1992). It is currently unclear whether this term has independently re-arisen, or is a resurfaced descendant of some scattered earlier usages. The present use of "bioeconomics" should be distinguished from a prior, temporarily floated use, from the 1970s, when "bioeconomics" referred to, for example, "tak[ing] fuller account of man's use of energy in economic activities." Georgescu: A Prophet of Energy Economics, Business Week, March 24, 1975, Industrial Edition. On the other hand, it seems similar to the usage of the term in a 1913 work, the earliest we can locate to use the term: Herman Reinheimer, Evolution by Co-operation: A Study in Bio-Economics (Dutton 1913). The earliest example we have located of the term's use in a science journal is William Borberg, Men and Their Sciences, 122 Science 183,185 (July 29, 1955). The earliest example we have located of the term's use in an economics journal is: Nicholas Georgescu-Roegen, Energy and Economic Myths, $41 \mathrm{~S}$ Econ J 347, 369 (1975) (reporting that the term was first seen in a letter (date uncertain) from Jiri Zeman).

${ }^{26}$ See, for example, http://www.economyprofessor.com/economictheories/bionom ics.php.

${ }^{27}$ See, for example, Ulrich Witt's entry on Evolutionary Economics in The New Palgrave Dictionary of Economics, online at http://www.dictionaryofeconomics .com/article?id=pde2008_E000295; David Boyce Hamilton, Evolutionary Economics: A Study of Change in Economic Thought (Transaction 1991); Gerhard Hanappi, Evolutionary Economics: The Evolutionary Revolution in the Social Sciences (Aldershot 1994); John Laurent \& John Nightingale, eds, Darwinism and Evolutionary Economics (Edward Elgar 2001); Jack Vromen, Conjectural Revisionary Economic Ontology: Outline of an Ambitious Research Agenda for Evolutionary Economics, 11 J Econ Methodology 213 (2004). See also, Thorbjorn Knudsen, Economic Selection Theory, 12 J Evolutionary Econ 443 (2002); Geoffrey M. Hodgson, Darwinism in Economics: From Analogy to Ontology, 12 J Evolutionary Econ 259 (2002); Trenton G. Smith \& Attila Tasnadi, A Theory of Natural Addiction, 59 Games \& Econ Behav 316 (2007).

The first mention we can locate of the term "evolutionary economics" is in an American Naturalist listing of programs at the World's Columbian Exposition of 1893. One program is there titled "Some American Problems of Evolutionary Economics." The first full article we can locate using the term is Veblen's in 1898 (cited in note 15$)$.

Somewhat confusingly, there is another use of the term "evolutionary economics," somewhat unrelated to the use described here. See, for example, An Association for Evolutionary Economics, online at http://www.afee.net/.

${ }^{28}$ Paul W. Glimcher, Decisions, Uncertainty, and the Brain: The Science of Neuroeconomics (MIT 2002); C. Camerer, et al, Neuroeconomics: How Neuroscience Can Inform Economics, J Econ Lit 9 (March 2005). 
- There are new journals such as the Journal of Bioeconomics ${ }^{29}$ and the Journal of Evolutionary Economics. ${ }^{30}$

- There is an international trend toward academic societies that join these disciplines, such as the International Society for Bioeconomics, ${ }^{31}$ and the Japan Association for Evolutionary Economics. ${ }^{32}$

- There are many significant journal articles-such as Economics from a Biological Viewpoint and Economic Models in Ecology and Law and Biology-that explicitly tie biology and economics together. ${ }^{33}$

${ }^{29}$ Contents of this journal, which began publication in 1999, can be viewed online at http://www.springerlink.com/content/1573-6989/.

${ }^{30}$ Contents of this journal, started in 1991, can be viewed online at http://www .springerlink.com/content/1432-1386/?p=aeaa69a117ac44de8e30358e764e2118 \&p_o=51.

${ }^{31}$ See mentions online at http://www.springerlink.com/content/g262n873318671 wg/fulltext.pdf and http://www.springer.com/west/home/economics/journals?SGW ID $=4-40532-70-35644198-0$.

${ }^{32}$ Japan Association for Evolutionary Economics, online at http://www.econ .kyoto-u.ac.jp/\%7Eevoeco/.

${ }^{33}$ Jack Hirshleifer, Economics From A Biological Viewpoint, $20 \mathrm{~J}$ L \& Econ 1 (1977); Jack Hirshleifer, Evolutionary Models in Economics and Law: Cooperation Versus Conflict Strategies, 4 Research L \& Econ 1 (1982); Jack Hirshleifer, Competition, Cooperation, and Conflict in Economics and Biology, 68 Econ \& Bio 238 (May 1978); Michael T. Ghiselin, The Economy of the Body, 68 Econ \& Bio 233 (May 1978); Michael T. Ghiselin, Darwin, Progress, and Economic Principles, 49 Evolution 1029 (1995); David J. Rapport \& James Turner, Economic Models in Ecology, 195 Science 367 (1977); Donald T. Campbell, Rationality and Utility from the Standpoint of Evolutionary Biology, 59 J Business S355 (1986); Hammerstein \& Hagen, (cited in note 25); Ulrich Witt, Economics, Sociobiology, and Behavioral Psychology on Preferences, $12 \mathrm{~J}$ of Econ Psych 557 (1991); Arthur J. Robson, The Biological Basis of Economic Behavior, 39 J of Econ Lit 11 (2001); Robert Boyd \& Peter J. Richerson, Sociobiology, Culture and Economic Theory, 1 J Econ Behav \& Org 97 (1980); Larry Samuelson \& Jeroen Swinkels, Information, Evolution and Utility, 1 Theoretical Econ 119 (2006); Larry Samuelson, Analogies, Adaptation, and Anomalies, 97 J of Econ Theory 320 (2001); Luis Rayo \& Gary S. Becker, Evolutionary Efficiency and Happiness, 115 J Political Econ 302 (2007); Herbert Gintis, A Framework for the Unification of the Behavioral Sciences, 30 Behavioral \& Brain Sciences 1 (2007); Hoffman, Law and Biology (cited in note 3); Donald Cox, Biological Basics and the Economics of the Family, $21 \mathrm{~J}$ of Econ Perspectives 91 (2007); Geoffrey M. Hodgson \& Thorbjørn Knudsen, In Search of General Evolutionary Principles: Why Darwinism is Too Important to be Left to the Biologists, 10 J Bioeconomics 51 (2008); Bart Du Laing, Equality in Exchange Revisited: From an Evolutionary (Genetic and Cultural) Point of View, in Law, Mind and Brain 267 (Michael Freeman \& Oliver R. Goodenough eds, Ashgate 2009); Bart Du Laing, Dual Inheritance Theory, Contract Law, and Institutional Change? Towards the Co-evolution of Behavior and Institutions, 9 German L J 491(2008). See also Felix Hoffler, Why Humans Care About Sunk Costs While Animals Don't: An Evolutionary Perspective, MPI Collective Goods Preprint No. 2005/17, online at SSRN: http:// ssrn.com/abstract $=808884$. 
- Similarly, there are numerous book chapters-such as Principles and Prospects for General Economy and Evolution, Learning, and Economic Behavior ${ }^{34}$ - that do the same. ${ }^{35}$

- And there have been a number of full-length books on the subject-such as Economics as An Evolutionary Science: From Utility to Fitness and Sociobiology and Bioeconomics: The Theory of Evolution in Biological and Economic Theory and Second Nature: Economic Origins of Human Evolution-exploring the overlaps of, and useful cross-fertilization between, economics and biology. ${ }^{36}$

To be sure, interdisciplinary scholars in either of these fields will disagree over the implications of the other field's insights. As Jack Vromen describes, economists working with evolutionary theory have broken themselves into three camps. One camp believes that incorporating evolutionary theory into economics requires no change in standard economic theory. A second camp thinks that the basic structure of economic theory can remain intact, but details differ when evolutionary theory is used. A third camp thinks that evolutionary insights necessitate a complete revision of economic theory. ${ }^{37}$ Moreover, economists interested in behavioral biology can confront a diversity of existing evolutionary approaches, ${ }^{38}$ just as biologists interested in economics can confront competing views of economic theory.

Nevertheless, all of these developments, historical and current, reveal that the connections between economics and biology are

${ }^{34}$ Reinhard Selten, Evolution, Learning, and Economic Behavior, 3 Games and Economic Behavior 3 (1991).

${ }^{35}$ See, for example, Michael T. Ghiselin, Principles and Prospects for General Economy, in Gerard Radnitzky \& Peter Bernholz, eds, Economic Imperialism: The Economic Approach Applied Outside the Field of Economics (Paragon House 1987).

${ }^{36}$ See, for example, Arthur E. Gandolfi, et al, Economics as Evolutionary Science: From Utility to Fitness (Transaction 2002). Geoffrey M. Hodgson, Economics and Evolution: Bringing Life Back into Economics (Michigan 1993). Michael T. Ghiselin, The Economy of Nature and the Evolution of Sex (California 1974); Paul Seabright, The Company of Strangers: A Natural History of Economic Life (Princeton 2004); Peter Koslowski, ed, Sociobiology and Bioeconomics: The Theory of Evolution in Biological and Economic Theory (Springer 1999); Eric D. Beinhocker, The Origin of Wealth: Evolution, Complexity, and the Radical Remaking of Economics (Harvard Business School 2006); Haim Ofek, Second Nature: Economic Origins of Human Evolution (Cambridge 2001).

${ }^{37}$ Jack J. Vromen, Taking Evolution Seriously: What Difference Does it Make for Economics?, in John Davis, et al, eds, The Elgar Companion to Economics and Philosophy 102, 103 (Edward Elgar 2004); Richard W. England, Evolutionary Concepts in Contemporary Economics (Michigan 1994).

${ }^{38}$ See generally, Kevin N. Laland \& Gillian R. Brown, Sense and Nonsense: Evolutionary Perspectives on Human Behaviour (Oxford 2002). 
deep, substantial, "deeply resonant" (in the words of Morris Hoff$\left.\operatorname{man}^{39}\right)$, and increasingly noticed. ${ }^{40}$ In sum, the deep structural relationship between economics and biology stems from the fact that both fields focus on maximizing outcomes in the face of scarcity and uncertainty. ${ }^{41}$ And, when scarcity becomes relevant to survival and reproduction, natural selection will (all else equal) favor those who economize. ${ }^{42}$ This has inevitable implications for the ways behavior-including behavior relevant to $\mathrm{law}^{43}$-is analyzed.

\section{ECONOMICS AND BIOLOGY}

The first step in comparing law and economics with law and behavioral biology is to compare economics and behavioral biology independent of law. ${ }^{44}$

\section{A. Similarities}

Beyond the fact that both fields deal with successful strategies for coping with scarcity, economics and behavioral biology are similar in many other, more specific ways. This section quickly surveys a variety of examples.

${ }^{39}$ Hoffman, Law and Biology at 1 (cited in note 3).

${ }^{40}$ See, for example, Daniel Nettle, reviewing Economics as an Evolutionary Science, 3 Human Nature Rev 21 (2003).

${ }^{41}$ Gordon Tullock, Some Personal Reflections on the History of Bioeconomics, 1 J of Bioecon 13 (1999).

${ }^{42}$ See generally, Alcock (cited in note 9); David D. Barash, The Survival Game Theory Explains the Biology of Cooperation and Competition (Henry Holt 2004).

${ }^{43}$ Our main purpose in this article is to explore comparisons rather than applications. There are a variety of existing applications, however. For example, one arc of research laid a theoretical foundation ("time-shifted rationality") for linking behavioral biology and economics in the law-relevant context of "endowment effects," then tested predictions of that foundation, and used the close fit between predictions and data to develop a new theory of endowment effects. See Time-Shifted Rationality and the Law of Law's Leverage (cited in note 6); S.F. Brosnan, et al, Endowment Effects in Chimpanzees, 17 Current Bio. 1704 (2007); Jones \& Brosnan, (cited in note 6).

${ }^{44}$ As should be clear from the foregoing, we are by no means the only scholars to explore various conceptual relationships between the two fields. See, for example, scholars cited in notes 20, 21,33-35; Hoffman (cited in note 3); Hodgson, Bringing Life Back (cited in note 36); Hodgson, Taxonomy (cited in note 24); Vromen, Taking Evolution Seriously (cited in note 37); Hammerstein \& Hagen (cited in note 22); R.R. Nelson \& S.G. Winter, An Evolutionary Theory of Economic Change (Belknap 1982); Paul Krugman, What Economists Can Learn from Evolutionary Theorists-and Vice Versa, in John Groenewegen \& Jack Vromen, eds, Institutions and the Evolution of Capitalism: Implications of Evolutionary Economics (Edward Elgar 1999) (1996 lecture to the European Association for Evolutionary Political Economy), online at: http://web.mit.edu/krugman/www/evolute.html. 
At the most basic (and most obvious) level, the central subject matter of both economics and behavioral biology is behavior. Note that in their approaches to behavior, both economics and biology assume that organisms can move toward optimal behavioral outcomes without focused, prior, cognitive deliberation. ${ }^{45}$

In studying behavior, both economics and biology seek to understand the mulitiple influences on behavior, and both fields are generally interested in generating probabilistic but general predictions about how most actors within large populations will behave. In generating these predictions, both disciplines begin with an assumption that, by and large, ${ }^{46}$ individuals behave in ways that reflect selfinterest (often streamlined down to wealth and reproductive success, respectively) and that groups therefore tend to behave in ways that reflect aggregated self-interest of constituent individuals. Moreover, because each field seeks to understand how scarce resources (including time and energy) can be efficiently allocated, each focuses on the extent to which behavioral inclinations vary as environments vary. In short, predicted behaviors are often context-specific.

As in many other fields, analyses in both economics and behavioral biology tend to begin with simple, generally-accessible concepts that are capable of yielding useful insights into their studied subjects. For instance, one of the central ideas in economics is that price is a function of supply and demand. ${ }^{47}$ If demand for a good increases, price will rise; if supply increases, price will fall. And one of the central ideas in behavioral biology - natural selection - is that, in a world of varying heritable traits, those that increase reproductive success more than others tend to appear in increasing proportions in subsequent generations of individuals. ${ }^{48}$

${ }^{45}$ The fields of biology and economics do differ, however, in the extent to which this assumption is invoked. It is more universally invoked in biology. Hirshleifer discusses this distinction in Hirshleifer, at 4 (cited in note 21).

${ }^{46}$ There is some debate in biology whether the unit of selection is the gene exclusively, or alternatively the gene, individual, group, or species, depending on context. See Ridley, at Chapter 12 (cited in note 9). The two extremes can be surveyed in Richard Dawkins, The Selfish Gene (Oxford 1976) and D.S. Wilson \& E. O. Wilson, Rethinking the Theoretical Foundation of Sociobiology, 82 Q Rev Biology 327 (2007), though most biologists continue to subscribe to the former of these two views. See Ridley, at 310-15 (cited in note 9). On the extent to which biological self interest and altruism toward kin, friends, or strangers can be reconciled, see Timothy H. Goldsmith \& William F. Zimmerman, Biology, Evolution, and Human Nature 126-38 (Wiley 2001).

${ }^{47}$ For a basic description, see Gary S. Becker, Economic Theory 4-7 (Knopf 1971).

${ }^{48}$ For a basic description, see Trivers, Social Evolution 15-17 (Benjamin Cummings Publishing Co. 1985). For further explanation, see Ridley, at 263-350 (cited in note 9). 
However, each field also contains subtle complexities that can confound newcomers. Take, for example, the important but nonobvious distinction in economics between "slopes" and "elasticities" of demand (or supply) curves. Both the slope and the elasticity of the demand curve measure the change in demand as price changes. In common shorthand, the two terms are used interchangeably, with a steeper demand curve also being described as less elastic. This usage is accurate in the two limiting cases, where perfect inelasticity is the same as a vertical demand curve and, at the other extreme, where infinite elasticity is the same as a horizontal demand curve. But elasticity and slope are not the same in cases between those extremes. The slope of a demand or supply curve is defined as the change in price divided by the corresponding change in quantity. If the price decreases by $\$ 1$ and demand increases by 10 units, the slope is $1 / 10$. If the price decreases by 1 dollar and demand increases by 1 unit, the slope is $1 / 1$, or 1 . The price elasticity of demand, by contrast, is defined as the percentage change in quantity demanded divided by the corresponding percentage change in price. ${ }^{49}$ If the price decreases from $\$ 5$ to $\$ 4$ and demand increases from 2 to 3 units, the elasticity is .5/-.2. When the "curve" is a slanted straight line, the slope will be the same at all prices but the elasticity will not. ${ }^{50}$ If the price decreases from $\$ 5$ to $\$ 4$ to $\$ 3$ while the number demanded increases from 2 to 3 to 4 units, the slope is 1 and the elasticity (under one definition) is $.5 /-.2$ for the first decrease and $.33 /-.25$ for the second decrease of a dollar in the price. Consequently, the slope varies as a function of measurement units, while the elasticity does not. If, in the example above, the units were dozens of items and the change in the number demanded is described as a change from 24 to 36 items instead of from 2 to 3 dozen, the slope is $1 / 12$ instead of 1 , but the elasticity remains at .5/-.2.

To take but one example of often-overlooked complexity in biol-

\footnotetext{
${ }^{49}$ Walter Nicholson, Microeconomic Theory: Basic Principles and Extensions 755 (Dryden, 3d ed, 1985). There are two types of elasticity, depending on the size of the change in price. It is called "point elasticity" when the change in price is infinitesimally small and "arc elasticity" when the change in price is larger than that. The arc elasticity depends on the size of the change in price. In addition, there are three ways of measuring the arc elasticity.

${ }^{50} \mathrm{On}$ a slanted straight demand curve, the coefficient of elasticity varies from infinity (minus infinity, but we ignore the minus sign) for an infinitely small change at the vertical axis intercept where quantity demanded is zero, to zero for an infinitesimal change at the horizontal axis intercept where price per unit is zero. Elasticity coefficients calculated for points or arcs at prices below the midpoint are below one, which is called "inelastic," while elasticity coefficients above the midpoint are above one, which is called "elastic." (The elasticity coefficient at the midpoint is precisely one.) For a treatment of the concept of elasticity, see Nicholson, at 172-82 (cited in note 49).
} 
ogy, people often assume that "fitness" can be measured by counting offspring. While this measure is certainly helpful, determining fitness is actually a bit more subtle. "Inclusive fitness" takes into account the varying probability-according to degrees of consanguinity-that copies of genes will appear in near relatives other than offspring, such as siblings, cousins, and nieces and nephews. ${ }^{51}$ Thus, and counterintuitively, there are some circumstances in which an individual could increase her fitness by limiting her own reproductive efforts (and thus offspring) and using the saved resources to increase the reproduction of genetic relatives. Fitness is a subtle concept in other ways, too. "Fitness" is relative, not absolute. It can be measured only with respect to a given environment. If the environment changes, what is "fitter" will change as well. ${ }^{52}$ Subtle complexities in the concepts of altruism, mutualism, cooperation, reciprocity, and group selection can also confuse newcomers..$^{53}$

Because each field uses models to predict behavior and, conversely, uses observed behavior to help test its models, identifying equilibrium behavior is important in each field. Without either a single or relatively small finite number of equilibria, a model's predictive usefulness is significantly hampered. ${ }^{54}$ In each field, the equilibrium sought is the solution to a constrained maximization problem. ${ }^{55}$ In both fields, the subject studied, if acting in her self interest, will maximize the value of desired outcomes. However, in both fields, the subjects also are assumed to be constrained by scarcity. Evolutionary processes (including natural selection, the oldest economizing force in the history of life) tend to favor heritable behaviors that maximize reproductive success, given limited intelligence, strength, material resources, and the like. Correspondingly, firms survive and

${ }^{51}$ Fitness can be viewed as a composite of both an individual's direct reproduction of genes (through mating and offspring) and that individual's indirect reproduction of genes (through increasing by aid the reproduction of genetic relatives). Alcock, at G-2 (cited in note 9). For a basic description of the concept of inclusive fitness, see Timothy H. Goldsmith, The Biological Roots of Human Nature: Forging Links Between Evolution and Behavior 39-41 (Oxford 1991).

${ }^{52}$ See generally, Douglas Futuyma, Evolution (Sinauer Associates 2005). For discussion, see Todd Zywicki, Evolutionary Psychology and the Social Sciences, 13 Humane Studies Rev, Issue 1 (Fall 2000).

${ }^{53}$ See generally, S.A. West, et al, Social Semantics: Altruism, Cooperation, Mutualism, Strong Reciprocity and Group Selection, 20 J Evol Biol 415 (2007).

${ }^{54}$ For a brief discussion of the problems created when multiple equilibria are possible, see, Douglas G. Baird, Robert H. Gertner \& Randal C. Picker, Game Theory and the Law 39 (Harvard 1994).

${ }^{55}$ See generally, Robert Cooter \& Thomas Ulen, Law and Economics 16 (Pearson Addison Wesley, 4th ed 2004) (describing relationship between equilibrium and maximizing behavior in economics). 
grow if they are better at maximizing profits than their competitors, given costly human and physical capital. ${ }^{56}$ Understanding the effects of scarcity is essential for identifying any interesting equilibrium behavior.

In both fields, subjects studied interact with others. In modeling behavior, then, it becomes necessary to incorporate a method for studying strategic interactions. So both fields draw at times on game theory for insights. ${ }^{57}$ In both fields, interactions are sometimes onetime interactions and other times are iterated, and optimal behaviors tend to vary depending upon which type of interaction people encounter. Moreover, some environments and situations render competitive strategies more successful than cooperative strategies, and vice versa. For instance, at its most basic level, zero-sum game settings tend to produce competition, while positive-sum game settings are more likely to produce cooperation. ${ }^{58}$ So each field has endeavored to sort and study the two types of strategies separately.

Cooperation enables animals, human and nonhuman, to achieve better outcomes, and it can enable them to compete more effectively with others. Economists typically study cooperation in the form of exchange, while biologists typically study cooperation as a form of mutualism, aid to kin, and reciprocal altruism. In both fields, though, stable cooperation is assumed to be in the self interest of all of its participants. In both fields, cooperation sometimes enables its participants to specialize, and specialization increases the total welfare for the participants by enabling them to reap larger gains and to do so at relatively smaller total expenditures of effort.

${ }^{56}$ On the relationship between profit maximization and survival, see Nicholson, at 335 (cited in note 49).

${ }^{57}$ In economics, see, for example, R. Duncan Luce \& Howard Raiffa, Games and Decisions: Introduction and Critical Survey (Wiley 1967); H. Scott Bierman \& Luis Fernandez, Game Theory with Economic Applications (Addison-Wesley 1993); Eric Rasmusen, Games and Information: An Introduction to Game Theory (Blackwell 1989). In biology, see, John Maynard Smith, Evolution and the Theory of Games (Cambridge 1982); Barash, (cited in note 42); Lee Alan Dugatkin \& Hudson Kern Reeve, Game Theory and Animal Behavior (Oxford 2000). For a crossover work, by an economist writing about game theory in the biological context, see, Herbert Gintis, Game Theory Evolving: A Problem-Centered Introduction to Modeling Strategic Behavior (Princeton 2000).

${ }^{58}$ With zero-sum games, one player loses what another gains, so the players are naturally competing with one another to obtain gains and avoid losses. With positive sum games, some outcomes will benefit both parties. To help obtain that mutual benefit, the parties are more inclined toward cooperation. See Scott Gates \& Brian D. Humes, Games, Information and Politics: Applying Game Theoretic Models to Political Science 2 \& n 4 (Michigan 1997) (discussing distinction between zero sum and positive sum games). 
Interactions, whether cooperative or competitive, are complex and messy in the real world. However, each discipline has found ways to generate equilibrium self-interested behavior without knowing everything there is to know about a given decision. One way to confront this complexity is to build uncertainty into the decision making environment. ${ }^{59}$ How should an organism respond, given limited, or asymmetric information? Another strategy for confronting complexity is to count on spontaneous coordination or order to result from multiple actions within each individual's self-interest. Economists study spontaneous order in the forms of markets and industries, while biologists study such order arising within social groups, and occasionally within or between species. Consequently, scholars in both economics and biology gain insights into complex phenomena by focusing on the aggregated effects of the behaviors of individuals.

Both economics and biology examine short-term changes in behavior that result from an exogenous change in the environment and long-term, domino effects on the behaviors of other actors and the actor herself..$^{60}$ One consequence of this separate analysis is that in both fields scholars are likely to distinguish carefully between behaviors that satisfy one's short-term interests and behaviors that serve one's long-term interests. In both fields, investment is a primary mechanism by which one trades off short-term and long-term benefits. Investing in college, or in a friendship, or in a business enterprise reflects short term costs in the form of forgone consumption opportunities. But that investment can yield long-term income or other benefits that prove to be far more valuable. From a biological perspective, animals often invest in offspring in ways that reduce the number of offspring one rears, while increasing their quality for future mating competition. Or they may invest in a social alliance that costs now, but may yield essential benefits later. From an inclusive fitness perspective, such behaviors may be optimal in the long run.

Models in both fields take account of the variety of ways that changes can arise. For example, a firm's fortunes may improve through conscious innovation, accidental discovery, or random misfortune (such as a hurricane) befalling a competitor. Analogously, in biology, an organism may out-compete its contemporaries as a consequence of some new beneficial genetic mutation, some beneficial new recombination of existing genes, or bad luck encountered by competitors.

${ }^{59}$ See, for example, Becker, at 57-66 (cited in note 9) (price theory lecture on the role of uncertainty in economic models).

${ }^{60}$ For a discussion of distinctions between short run and long run analyses in economics, see Nicholson, at 298-319 (cited in note 49). 
In addition, both fields consider ways in which efficient behavior tends to survive and repeat or reappear. In economics, this repetition may manifest within a person, a firm, or an industry. It may also manifest across persons, firms, and industries. When it manifests, depending on context, repetition may be a function of one or more of the following: observed and evaluated effects of accident or innovation; simple imitation of others; learning from observing and analyzing the behaviors of others; mere continuation of things that have not yet resulted in disaster. ${ }^{61}$ In biology, the repetition of interest is ordinarily trans-generational (though there are exceptions), and these are ordinarily tabulated in copies of genes (which, all else being equal, will increase proportionally over generations when inclining organisms toward efficient behaviors). However, human behavioral biology also accommodates the extent to which cultural influences and evolved cognitive capacities can enable people either to identify and deliberatively choose efficient behavior, or to imitate it for reasons of cultural relatedness, independent of genetic relatedness. ${ }^{62}$

The methodological tenets of the fields are similar and appealing to outsiders. As sciences, both fields aspire to creating hypotheses that are useful in predicting empirical observations. ${ }^{63}$ And scholars in each share a desire to generate models that are both internally consistent and consistent with one another. On one hand, this consistency contributes to conceptual elegance in both fields. On the other, it sometimes impedes in both fields the ability to closely analyze the validity of the assumptions that tend to underlie many long-standing models. ${ }^{64}$

Economics and behavioral biology are both easily (and in fact commonly) caricatured with straw-men attacks and both confront

${ }^{61}$ For a brief treatment of innovation and its spread, see Nicholson, at 273-75 /cited in note 49$)$.

${ }^{62}$ See generally, Peter J. Richerson \& Robert Boyd, Not By Genes Alone: How Culture Transformed Human Evolution (Chicago 2004); Robert Boyd \& Peter J. Richerson, The Origin and Evolution of Cultures (Oxford 2005); Robert Boyd \& Peter J. Richerson, Sociobiology, Culture and Economic Theory, 1 J Econ Behav \& Org 97 (1980) (arguing that biology can be attractive to economists only by taking into account the role of human culture); Joseph Henrich \& Richard McElreath, Dual-Inheritance Theory: The Evolution of Human Cultural Capacities and Cultural Evolution, in R.I.M. Dunbar \& Louise Barrett, eds, The Oxford Handbook of Evolutionary Psychology 555 (Oxford 2007).

${ }^{63}$ See, for example, Milton Friedman, The Methodology of Positive Economics, in Milton Friedman, Essays in Positive Economics 3-43 (Chicago 1935) (the ultimate goal of economics is "the development of a 'theory' or 'hypothesis' that yields valid and meaningful (i.e., not truistic) predictions about phenomena not yet observed.").

${ }^{64}$ It should be noted here that Friedman, for one, argued that examination of the validity of the assumptions was not a particularly important occupation. Id. 
supposed "refutations" constructed on the basis of a single example when of course no one in either field would contend that their theory describes or predicts the behavior of everyone. And the two fields have in common at least two charges from critics. First, each has been accused of being inherently politically conservative (or at least too-easily playing into the hands of conservatives). ${ }^{65}$ This tends to make conservative audiences too receptive, and liberal audiences too skeptical. Second, each has been accused of being too reductionistic. ${ }^{66}$ This charge provides cover for those who claim that human behavior is simply too complex to make the study of economic or biological influences on human behavior worthwhile.

Some of the core challenges for both fields are similar, in that each discipline must at one time or another confront behavioral complexity in the form of seemingly irrational or maladaptive behavior. ${ }^{67}$ For instance, both altruistic and spiteful behaviors require explanation and reconciliation with the underlying theories. ${ }^{68}$ Moreover, in the human contexts that concern us here, each discipline confronts

${ }^{65}$ See, for example, Richard A. Posner, Economic Analysis of Law 27 (Aspen 6th ed. 2002); Anita Bernstein, Whatever Happened to Law and Economics?, $64 \mathrm{Md} \mathrm{L} \mathrm{Rev} 101$ (2005); Arthur Leff, Economic Analysis of Law: Some Realism About Nominalism, 60 Va L Rev 451 (1974); Duncan Kennedy, Cost-Benefit Analysis of Entitlement Problems: A Critique, 33 Stan L Rev 387 (1981). But others dispute the claim that rational choice methods imply conservative outcomes. See, for example, David B. Spence, A Public Choice Progressivism, Continued, 87 Cornell L Rev 397 (2002); David B. Spence, The Shadow of the Rational Polluter: Rethinking the Role of the Rational Actor Model in Environmental Law, 89 Cal L Rev 917 (2001); David B. Spence \& Frank Cross, A Public Choice Case for the Administrative State, 89 Geo L J 97 (2000). As to behavioral biology, see Richard Lewontin, et al, Not in Our Genes: Biology, Ideology, and Human Nature (Pantheon 1984). For an overview, see Ullica Segerstralle, Defenders of the Truth: The Sociobiology Debate (Oxford 2001).

${ }^{66}$ For a discussion of reductionism charges in economics, see Maxwell L. Stearns, Public Choice and Public Law: Readings and Commentary 69-70 (Anderson 1997); see also, Abner J. Mikva, Symposium on the Theory of Public Choice: Foreword, 74 Va L Rev 167 (1988) (making similar accusation about economic theories of political behavior). For a discussion of these charges in biology, see Lewontin, et al (cited in note 65); Hodgson, at 235-51(cited in note 24) (addressing the problem of reductionism in biology and economics); Goldsmith, at 139-41 (cited in note 51).

${ }^{67}$ See, for example, Francesco Parisi \& Vernon Smith, eds, The Law and Economics of Irrational Behavior (Stanford 2005); Christine Jolls, et al, A Behavioral Approach to Law and Economics, 50 Stanford L Rev 1471 (1998). For analysis of how biology can illuminate various puzzles of economic irrationality, see Jones, Time-Shifted Rationality and the Law of Law's Leverage (cited in note 6).

${ }^{68}$ Robert Frank does a nice job of explaining how both spiteful and altruistic behaviors can be accommodated within the concept of self-interest. Robert H. Frank, Passions Within Reason: The Strategic Role of the Emotions (Norton 1988). See also, Timothy H. Goldsmith \& William F. Zimmerman, Biology, Evolution, and Human Nature 126-38 (Wiley 2001). 
(though often by different names) a variety of cognitive biases and heuristics that - at least at first-seem paradoxical given the main theoretical understructure. Common examples include hyperbolic discounting, endowment effects, hindsight bias, confirmation bias, and categorization by elimination. ${ }^{69}$

These similarities explain why the literatures in economics and behavioral biology often resonate with one another, and why biologists and economists are frequently drawn to each other's disciplines.

\section{B. Differences}

Notwithstanding the important similarities just briefly described, there are a number of significant differences between economics and behavioral biology. These differences, surveyed briefly in this section, can at times limit the usefulness of each discipline to the other. However, some of the differences actually suggest synergistic benefits that can be obtained through cross-fertilization.

The methods of the two disciplines differ in an important, threshold way. Economics is embedded within social science traditions, while behavioral biology is embedded within life science traditions. As a consequence, economists and biologists differ in training, tools, techniques, and even vocabulary. And these differences can cause scholars in the two fields to talk past one another or to at least initially overlook the merits of one another's advances. ${ }^{70}$

Historically, economics has focused primarily on humans, and only rarely and recently has ventured into non-human contexts. The reverse sequence is true for behavioral biology, which historically focused on nonhumans, and then gradually extended into human contexts. As a consequence, economists often overlook the extent to which human choices can be contextualized within the behavioral choices and tendencies of animals generally. By missing these connections, economists also can miss the implications for how an understanding of natural selection can deepen our understanding of human behavior. Conversely, biologists are sometimes uncomfortable plying their skills beyond non-human species, not only because humans are more behaviorally complex, and their behavioral biology

${ }^{69}$ For a discussion of these and other heuristics and biases, see Gerd Gigerenzer, et al, Simple Heuristics That Make Us Smart (Oxford 1999); Daniel Kahneman, et al, The Endowment Effect, Loss Aversion, and Status Quo Bias, 5 J Econ Persp 193 (1991); Daniel Kahneman et al, eds, Judgment under Uncertainty: Heuristics and Biases (Cambridge 1982).

${ }^{70}$ For examples of the disciplines being slow to adopt advances made by the other, see Hammerstein and Hagen, at 604-09 (cited in note 22). 
more politically controversial, but also because humans were simply exempted, for a long period of the history of the discipline, from the spectrum of the animal kingdom that biologists were trained to investigate.

With respect to particular foci of study, economics is concerned principally with market behavior (with some extensions into nonmarket behavior ${ }^{71}$ ), while behavioral biology is focused principally on non-market behaviors (with some extensions into market behaviors $^{72}$ ). Even where their analytic tools are similar, then, scholars in the two fields are not always interested in using those tools to explore the same questions.

Moreover, even when they are focused on the same market or nonmarket human behaviors, the canonical inquiries within the disciplines also vary significantly. Economists are mostly concerned with the "how" questions-such as how people are likely to respond to particular costs and benefits, given assumptions about their preferences. In other words, and ignoring important exceptions, ${ }^{73}$ economists usually treat preferences as exogenous, and are often loathe to explore either those preferences or their sources. Behavioral biologists are similarly concerned with these "how" questions, but their interests extend beyond them. Once organisms within a species are known to behave according to a particular set of preferences, biologists then ask "why" they may have those preferences. This naturally leads to consideration of evolutionary processes, including the effects of natural selection on behavioral predispositions.

To the economist, behavior reveals preferences. Future behavior can be predicted from those preferences, regardless of origins, which seem needless if preferences are clear and predictions confirmed. These differing perspectives may usefully join, however, since people have differing, sometimes competing preferences, and an inquiry into the source of those preferences can better help us pick and choose between preference possibilities to better predict behavior. For example, what environmental factors, perceived by a brain evolved to incline behavior in different ways in reaction to different environmental conditions, will increase the probability of cooperative

${ }^{71}$ See, for example, Gary Becker, A Treatise on the Family (Harvard 1981); Gary S. Becker \& William M. Landes, eds, Essays in the Economics of Crime and Punishment (National Bureau of Economic Research 1974).

${ }^{72}$ See, for example, Randolph M. Nesse, ed, Evolution and the Capacity for Commitment (Russell Sage Foundation 2001).

${ }^{73}$ See, for example, Paul H. Rubin \& Chris W. Paul II, An Evolutionary Model of Taste for Risk, 17 Econ Inquiry 585 (1979); Gary S. Becker, Accounting for Tastes (Harvard 1996). 
behavior, or competitive behavior? When and where are we likely to observe risky behavior? ${ }^{74}$

Insights into questions such as these may often benefit from sustained inquiry into both the how and the why questions. (Biologists distinguish these, respectively, as the necessarily complementary "proximate," mechanistic questions on one hand and the "ultimate," evolutionary history questions on the other. ${ }^{75}$ ) Moreover, a concern with the source of tastes may at times give behavioral biology an advantage for legal analyses. Attention to the sources of tastes allows not only consideration of how to change choices by changing prices, it also allows anticipation of the varying difficulties law or other nonmonetary pressures may encounter when attempting either to change the tastes themselves or to alter behavior reflecting those tastes. ${ }^{76}$ Finally, preferences about future states invoke brain processes that often incline subjects to erroneous predictions of their future welfare, and behavioral biologists and cognitive neuroscientists are contributing to a deeper understanding of the causes and consequences of these errors. ${ }^{77}$

There is also a significant difference between economics and behavioral biology in the dangerous ease with which people move from positive analysis to normative conclusions. To derive a prescriptive "ought" solely from a descriptive "is" is generally to commit a logical error sometimes referred to as the "naturalistic fallacy." ${ }^{\prime 78}$ To

\footnotetext{
${ }^{74}$ For an early attempt to explore these questions, see Rubin \& Paul (cited in note 73$)$.

${ }^{75}$ For discussion of these central concepts, see Alcock, Animal Behavior, at 2-6 (cited in note 9); Goldsmith, at 6-11 (cited in note 51); John Alcock \& Paul Sherman, The Utility of the Proximate-Ultimate Dichotomy in Ethology, 96 Ethology 58 (1994); Ernst Mayr, Cause and Effect in Biology, 134 Science 1501 (1961).

${ }^{76}$ See Time-Shifted Rationality and the Law of Law's Leverage (cited in note 6).

${ }_{77}$ See, for example, Daniel T. Gilbert \& Timothy D. Wilson, Prospection: Experiencing the Future, 317 Science 1351 (2007).

${ }^{78}$ See David Hume, A Treatise of Human Nature 469-70 (L.A. Selby-Bigge \& P.H. Nidditch, eds, Oxford, 2d ed 1978) (1740); and G.E. Moore, Principia Ethica 90 (Thomas Baldwin, ed, Cambridge rev ed 1993). We recognize that some object to the merging of Moore's "naturalistic fallacy" with Hume's "is-ought" distinction. See William H. Bruening, Moore and Is-Ought, 81 Ethics 143 (1971) (discussing whether the naturalistic fallacy and the is-ought distinction are the same). We are also aware that it is technically possible to derive ought from is in some narrowly-defined circumstances. Nonetheless, it is often a mark of defective reasoning. For arguments that biologists have paid too much attention to the naturalistic fallacy and too little attention to evolutionary ethics, see D. Wilson, et al, On the Inappropriate Use of the Naturalistic Fallacy in Evolutionary Psychology, 18 Bio \& Phil 669 (2003); Oliver Curry, Who's Afraid Of The Naturalistic Fallacy?, 4 Evol Psychol 234 (2006); Alex Walter, The Anti-Naturalistic Fallacy: Evolutionary Moral Psychology and the Insistence of Brute Facts, 4 Evol Psychol 33 (2006).
} 
put it in economic terms, it is not necessarily the case that efficiency should always be furthered, given that it could come at the cost of more important competing goals. However, it is easy to slide from the descriptive to the prescriptive. For example, a change that improves the lives of individuals might not be a good thing if it harms the collective. Some, perhaps especially some in other, less individualistic cultures, might be willing to argue that the unit that matters is the social unit, the tribe or nation, rather than the individual. Discussions about what is efficient make it hard for such views to find a place in the normative conversation because they are outside the traditional economic calculus.

Moreover, many efficiency arguments are grounded in KaldorHicks efficiency. Changes are Kaldor-Hicks efficient if total benefits exceed total costs. ${ }^{79}$ A change can be efficient under this definition even though some individuals will be made worse off by the change. ${ }^{80}$ Additionally, this notion of efficiency requires that the evaluator compare losses of one person to gains of another. It might be efficient, for example, for the government to make a poor person a bit worse off in order to make a rich person a lot better off. ${ }^{81}$ Since law and econom-

${ }^{79}$ Kaldor-Hicks efficiency is sometimes described as "potential Pareto efficiency". If side payments from winners to losers could be made, a Kaldor-Hicks efficient change could be converted into a Pareto efficient change. But the side payments are not made and changes can be Kaldor-Hicks efficient even though some parties are worse off for the change.

${ }^{80}$ Robert Cooter \& Thomas Ulen, Law and Economics 48 (Pearson Addison Wesley, 4th ed. 2004).

${ }^{81}$ To take a different example, suppose that the government has a house that it does not need any longer and which it decides to give away. Only two citizens want the house, a poor woman and a rich man. Suppose the government knows that the woman would value the house at exactly $\$ 10,000$ and the man would value the house at exactly $\$ 50,000$. If the house is given to the man, it would be possible for the man to pay the woman $\$ 30,000$ and make both of them happier than if the house were given to the woman. Since it would be possible for the winner to make such a payment, awarding the house to the rich man is the efficient choice, according to the Kaldor-Hicks test, even if that transfer payment is never made. Now suppose, in addition, that the poor woman would get more utility out of the house than the rich man. In such a case, the efficient decision under the Kaldor-Hicks concept of efficiency is at odds with the decision that will generate the greater increase in happiness.

Moreover, what do we mean when we say that a change will make people better or worse off? Maybe we are talking about monetary wealth, maybe peace of mind, maybe personal security. If we leave the objective unspecified, then it is easier to be convinced by the normative analysis that follows. But sometimes economists too get accused of turning their positive analysis into contentious normative claims. Suppose, for example, that a rapist can get so much positive utility from a rape that his benefits exceed the costs to the rape victim. The rape is Kaldor-Hicks efficient, and yet virtually no one believes as a normative matter that the rape should be legal, let alone encouraged. 
ics analysis often applies, whether expressly or impliedly, the KaldorHicks criterion, policy makers ought not jump from the statement that a change is efficient to the conclusion that the change is desirable. ${ }^{82}$ However, "efficiency" evokes such strongly favorable sentiments that once it is determined that choice $\mathrm{A}$ is more efficient than choice B, many will find that analysis sufficient to justify choice A. Because efficiency is like motherhood and apple pie, an analysis that shows one law to be more efficient than another law as a matter of positive analysis also has assumed normative implications even though the logical connection has not been established. There is, at least today, ${ }^{83}$ no correspondingly seductive connection between what is reproductively successful and what is "good". Therefore, it is much easier to avoid the mistake of drawing a normative implication from a biological description. For example, reproductive success may be "good" for organisms and genes. But those who try to make the unwarranted jump to the conclusion that policies that would increase reproductive success should be pursued for that reason will immediately be asked to explain why this is so. Whereas the very idea of "efficiency" sounds normatively attractive (who argues for the virtue of inefficiency?), the normative implication of reproduction, in contrast, is obviously contextually embedded, and lacking in universal appeal. ${ }^{84}$

Economics and biology also approach the subject of change rather differently. Earlier we treated innovation and mutation as similar concepts precisely because each enables models of humans and

\footnotetext{
${ }^{82}$ The Kaldor-Hicks criterion is obviously normative. Not only can it be put to prescriptive purposes, it seems to have been designed for use in normative analysis. One positive purpose to which the Kaldor-Hicks definition can be put is in the hypothesis that a branch of government behaves in a such way as to achieve Kaldor-Hicks efficiency. For example, one might argue that common law courts come to rules that are efficient in that sense. See, for example, Posner, Economic Analysis of Law (Aspen, 7th ed. 2007). It is not a large step from that hypothesis, however, to the argument that the common law rules are good rules. There is no corresponding normative standard in biology.

${ }^{83}$ Social Darwinism (more properly "Social Spencerism", see Jones \& Goldsmith, at 492-94 (cited in note 4)) no longer has much support among those who make or influence policy. But this should raise a cautionary flag for law and economics. If policy makers could make the stupefying leap from what is reproductive to what is good, it should be all the easier to make the seemingly smaller jump from what is efficient to what is good. One lesson that we might take from the biologists' caution is to better question the assumptions regarding preferences, costs, and benefits that underlie the efficiency analysis used in economics.

${ }^{84}$ Note, too, that the subjects of economics (efficient regulation of markets, for example) frequently evoke less emotional reactions than reproductive biology (for example, children). This may be one more reason why the assumptions of the economist are more likely to remain unobserved by the student than are the assumptions of the biologist.
} 
human behavior to incorporate change. ${ }^{85}$ But the changes occur differently in each realm. Consider first innovation: a good idea can often quickly induce long-lasting and productive change. This is less true in biology, where all genetically heritable changes are, with the exception of modern technological manipulations, the function of genetic mutation or recombination. Natural selection may sort genes and genetic combinations. But nature does not create new ones as a function of some perceived opportunity. And humans cannot, at least without significant technological advancement, create significant genetic changes for the species by consciously responding to new opportunities. In short, in biology, there is no watchmaker; in economics there is. ${ }^{86}$

Because economically relevant change is easier for humans, economic behavior is more easily modified by moving directly between local optima than is biological behavior change. For example, a car company might entirely abandon one method of supplying its factories to instead imitate another company's more successful method. In contrast, evolutionary biologists tend to study changes in behavior that are unlikely to reflect movement directly between local optima. The biological constraint stems from the fact that organisms are path dependent and unlikely to move to a suboptimal position, even if it might eventually lead to a superior local optimum, and from the fact that organisms can only work with the variability genetics supplies, ${ }^{87}$ not with the variability that a good idea or experienced need might recommend. ${ }^{88}$

Another difference between economics and biology revolves

${ }^{85}$ See Part IV.A.

${ }^{86}$ Some current critics of Darwinism rely on an old "watchmaker" argument for the existence of God, an argument that Darwin himself rebutted. The essence of the argument is that anatomical features that perform certain functions so well must have been designed to do so by some designer, just as a watch must have been designed by a watchmaker. See David Hume, Dialogues Pt. II; William Paley, Natural Theology (Printed for Daniel and Samuel Whiting, 6th ed 1803). The argument is an evolved form of one that dates back at least to Cicero. "When you see a sundial or a waterclock, you see that it tells the time by design and not by chance. How then can you imagine that the universe as a whole is devoid of purpose and intelligence, when it embraces everything, including the artifacts themselves and the artificers." Cicero, as quoted in Daniel C. Dennett, Darwin's Dangerous Idea (Simon \& Schuster 1995) at 29 n 5. See also, Richard Dawkins, The Blind Watchmaker (Norton 1986).

${ }^{87}$ For a discussion of movement between local optima and their limitations in biology, see Timothy H. Goldsmith, The Biological Roots of Human Nature: Forging Links Between Evolution and Behavior 34 (Oxford 1991).

${ }^{88}$ Dawkins is reported to have said something to the effect of: No one would expect pigs to sprout wings, notwithstanding that they could come in handy from time to time. Relatedly, see Kam Patel, Going the Whole Hog, The Times Higher Education Supplement (Apr 28, 1995) (interviewing Richard Dawkins). 
around the concept of consumption. It was pointed out above that the idea of investment is critically important to both disciplines. However, the idea of individual consumption-just for its own sake-is not similarly shared. From the biological point of view, any deployment of resources that does not contribute directly or indirectly to reproduction (at least of relatives) is arguably wasteful. And animals that engage in wasteful behaviors may in the long run, be less reproductive than contemporaries inclined to behave more efficiently. If so, heritable inclinations toward less productive behavior risk being wiped out by the economizing force of natural selection. Consequently, whereas economists are comfortable contemplating tradeoffs between consumption and investment, biologists generally continue to analyze only tradeoffs among investments.

These differences between economics and biology, and others like them, underscore why economists and biologists do not always see eye to eye, and why it would be a mistake to assume that biological and economic insights will always converge.

\section{LAW \& ECONOMICS MEETS LAW \& B E H A V I O R A L B I O L O G Y}

Against the background of the prior Part, we can now consider the similarities and differences between the intersection of law and economics, on one hand, and law and behavioral biology, on the other.

\section{A. Similarities}

Obviously, the core similarities of the underlying disciplines discussed in Part III generate similarities in the ways that each field intersects with law. Beyond those already mentioned, there are a few additional similarities to note.

Because both economics and behavioral biology develop theoretical constructs for explaining and predicting human behaviors, each subfield of law attracts scholars interested in improving law's functioning by applying or even improving its theories of human behavior. Not surprisingly, then, there are some key overlapping personnel. For example, a number of prominent law and economics scholars—-such as Richard Epstein, ${ }^{89}$ Mark Grady, ${ }^{90}$ Richard Posner, ${ }^{91}$

\footnotetext{
${ }^{89}$ See, for example, Richard Epstein, A Taste for Privacy?: Evolution and the Emergence of a Naturalistic Ethic, 9 J Leg Stud 665 (1980); Richard Epstein, The Varieties of Self-Interest, 8 Social Phil \& Pol 102 (1990).

${ }^{90}$ See, for example, Mark Grady \& M.T. McGuire, A Theory of the Origin of Natural Law, 8 J Contemp Legal Issues 87 (1997); Mark Grady \& M.T. McGuire, The Nature of Constitutions, 1 J Bioeconomics 227 (1999).

${ }^{91}$ See, for example, Richard Posner, Sex and Reason (Harvard 1992).
} 


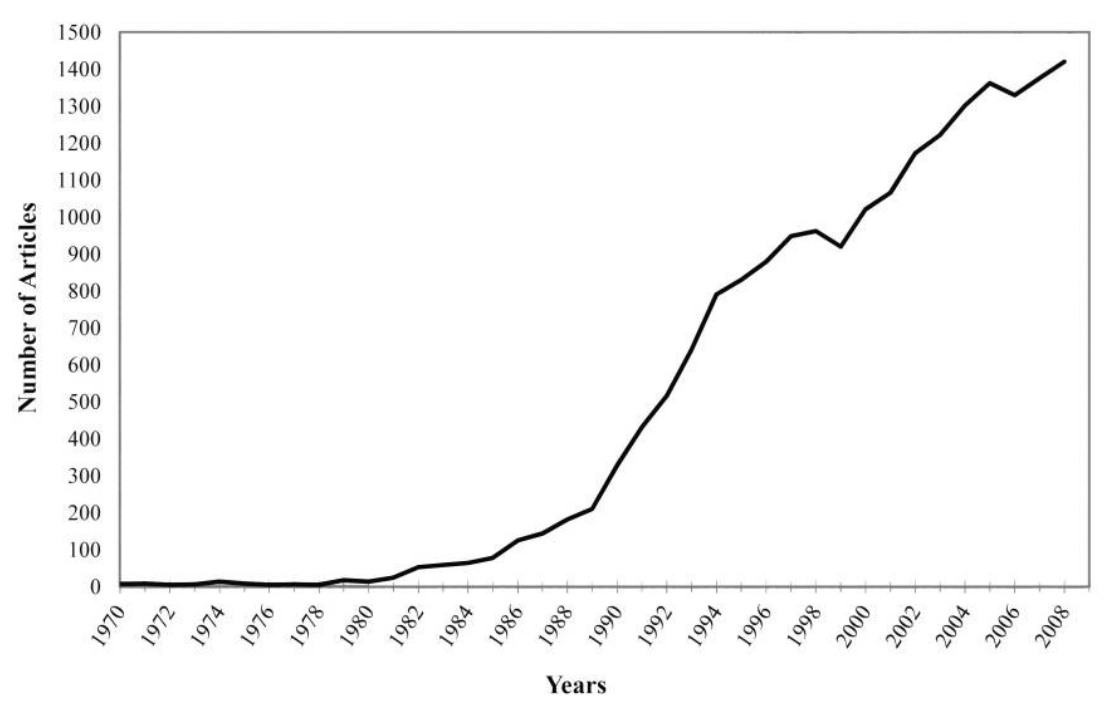

Figure 1. Articles in Westlaw "Journals \& Law Reviews" Database. Search term: dates (is [year]) \& evol! \& biolog! \& econ!

and Paul Rubin ${ }^{92}$ - have already drawn attention in legal contexts to important parallels between economics and biology. And the annual number of articles in law that mention biology, evolution, and economics in the same piece, in one way or another, shows a nearly constantly upward trend, by year, with roughly 1418 law review articles in 2008 alone. ${ }^{93}$ (See Figure 1.)

Because each subfield of law seeks a unifying theory for both human behavior and law, each sparks concerns about possible disciplinary imperialism. This inevitably raises suspicions of political motives, which have been compounded in part by the openly conservative perspectives of some of the scholars just mentioned. Indeed, some skeptics of law and biology have expressed concern that the study of human behavioral biology might somehow inherently appeal to

${ }^{92}$ See, for example, Paul H. Rubin, Why is the Common Law Efficient?, 6 J Leg Stud 51 (1977) reprinted in Paul Rubin, ed, The Evolution of Efficient Common Law (Edward Elgar 2007); Paul Rubin, Darwinian Politics: The Evolutionary Origin of Freedom (Rutgers 2003).

${ }_{93}$ This evidence is illustrative, but imperfect. First, it would be useful to also know percentage trends, which would require correction for differences from year to year in the total number of law review articles published. (That is, the number of articles combining these terms could be increasing at the same time that the percentage combining them is decreasing.) Second, the search term is very rough. It is likely over-inclusive in some ways, and under-inclusive in others. For an article combining law, economics, and evolutionary biology, see for example Mark Roe, Chaos and Evolution in Law and Economics, 109 Harv L Rev 641 (1996). 
those with a penchant to politicize issues. ${ }^{94}$ Will conservative scholars turn to law and behavioral biology as a tool, to be deployed in ways consistent with (broadly speaking) conservative agendas? Or reciprocally, for that matter, will liberal scholars turn law and behavioral biology into a tool, to be deployed in ways consistent with (broadly speaking) liberal agendas? Our own view is that neither of these forms of politicization is either inevitable or desirable. As with law and economics, the theoretical construct and empirical insights derived from behavioral biology should appeal to legal scholars who merely wish to better understand our world, its current legal policies, and the potential impact of future policy reforms. To succeed at this endeavor, however, scholars in law and behavioral biology must proceed cautiously. We therefore revisit this issue in Part V.

Another similarity between the intersections of economics and biology with law concerns the difficulty of achieving an appropriate balance, for legal readers, between main themes and subtle details. As a consequence of the interplay between main themes that are quickly accessible, and subtleties that are not, law and economics had to find ways, in early years, to educate readers on the basics of a technical discipline, before one could then explore possible implications in legal contexts. The same is true for law and biology. Striking the right balance is more challenging than it might first appear, and more important than its inherently procedural nature may sound, given the subtleties that must inevitably be skipped in summarizing fundamentals, the need to repeat key concepts for those new to the topic, and the limitations on space and reader patience for background information before getting to interesting applications.

As John Monahan has argued in overview, ${ }^{95}$ both law and behavioral biology, on one hand, and law and economics, on the other, have great heuristic power, great breadth, and great depth. The similar heuristic power stems from the abilities of each to raise large sets of interconnected questions, and also to explore those questions empirically. Clearly, this does not and should not dictate conclusions about what we should and should not do with legal policy. Yet, at the same time, the two interdisciplinary fields can each help us learn more

${ }^{94}$ This was, for example, one of the major concerns expressed at a conference on behavioral biology and feminism, at Emory University Law School, in December 2006. (And this may have reflected in part the perception, signalled in the conference Call for Papers, that law and economics scholars may be especially prone to find evolutionary perspectives appealing; the Call for Papers had indicated that a key topic of inquiry should be: "The relationship between evolutionary biology and economics, and between the emerging field of "Law and Evolution" and the established field of Law and Economics.") Moreover, the possible relationship between biology and conservatism has garnered continuing attention in both academic and media outlets. See, for example, A Split Emerges as Conservatives Discuss Darwin, New York Times, May 5, 2007.

${ }^{95}$ Monahan (cited in note 2). 
about the underlying causes of and patterns in behaviors that matter to us. This may thereby aid the efficient and effective pursuit with legal tools of social goals already in place, and also help us better anticipate how various legal interventions may affect future behavior in both intended and unintended ways.

The great breadth to which Monahan refers reflects the fact that both interdisciplinary areas address extraordinarily wide ranges of behavior, with general principles of broad applicability. Because the theories and findings of economics and behavioral biology are not limited to particular human activities, there is potential for utility, in law, across a wide range of legal contexts. ${ }^{96}$ And the great depth to which Monahan refers reflects the fact that both interdisciplinary areas hold promise to extend far below surface generalities. These interdisciplinary areas provide tools that can penetrate into specific legal contexts. And, each is capable of generating sophisticated, often counterintuitive insights into human behavior and law. ${ }^{97}$

\footnotetext{
${ }^{96}$ In law and economics, this was demonstrated most vividly by Richard Posner's book Economic Analysis of Law. There are also numerous applications in law and behavioral biology (see www.sealsite.org). For example, Jones \& Goldsmith (cited in note 4), catalogue, describe, and illustrate a large set of applications, including: discovering useful patterns in regulable behavior; uncovering conflicts among contemporaneously pursued legal policies; sharpening the cost-benefit analyses that often influence legal policymaking; clarifying links between various causal influences and their effects on human behavior; increasing our understanding about human decisionmaking; providing theoretical foundation for, and potential predictive power about, a variety of human behaviors; disentangling the multiple causes of various lawrelevant behaviors; exposing a variety of unwarranted assumptions underlying legal approaches for inspiring behavioral changes; assessing the comparative effectiveness of legal strategies we employ to change specific behaviors; revealing deep patterns in legal architecture; and identifying under-noticed and unintended selection pressures that legal systems can themselves create.

${ }^{97}$ See, for example, Jeffrey Evans Stake, Mandatory Planning for Divorce, 45 Vand L Rev 397 (1992) (efficiency could be advanced by requiring people to plan for divorce at the time of marriage); Jones \& Goldsmith (cited in note 4); Maxwell L. Stearns, The Public Choice Case Against the Item Veto, 49 Wash \& Lee L Rev 385 (1992) (using economic analysis to argue that a line item veto would not reduce pork barrel spending but might enhance the President's influence over public interest legislation); Linda Cohen \& Matthew Spitzer, Term Limits, 80 Geo L J 477 (1992) (using economic analysis to argue that term limits enhance interest group influence on legislators); John J. Donohue \& Peter Seigelman, The Changing Nature of Employment Discrimination Litigation, 43 Stan L Rev 983, 1024 (1991) (laws against discrimination in firing employees may increase discrimination in hiring); Jeremy Bentham, Defence of Usury, Shewing the Impolity of the Present Legal Restraints on the Terms of Pecuniary Bargains in a Series of Letters to a Friend. To Which is Added a Letter to Adam Smith, Esq; LL.D. on the Discouragements Opposed by the Above Restraints to the Progress of Inventive Industry (1787) (laws against usury hurt borrowers); George L. Priest \& Benjamin Klein, The Selection of Disputes for Litigation, 13 J Leg Stud 1 (1984) (whether the law is pro-plaintiff or pro-defendant cannot be determined by the percentage of cases won); Robert P. Albon, Lawyers and the Rental Market for Hous-
} 


\section{B. Differences}

As with the similarities, the core differences between economics and behavioral biology also seem to generate differences in the ways in which each field intersects with law. For example, because economics has long focused on human behavior, economic concepts can be easily transported to the human context without objection by legal academics. In contrast, because behavioral biology has only more recently focused on the biological underpinnings of human behavior, it is natural for legal academics to initially question its fundamental applicability to law.

Moreover, in particular legal contexts, one field's tools can be relatively more useful than the other's. For example, law and economics holds the promise of analyses that translate a specific change in one thing (say, minimum wage, or a tax on gasoline) into a specific change in another (say, the unemployment rate, or consumption of gasoline and purchase of SUVs). In contrast, law and behavioral biology will do relatively less well at predicting changes in modern law, economies, and other cultural environments. At the same time, behavioral biology is relatively better equipped to explain preferences (as well as changes in preferences) and to both explain and predict some of the human behaviors those preferences generate. For example, biology is better at explaining why some behaviors are relatively unresponsive to marginal legal changes. Moreover, the biological models do a better job of both explaining and predicting behaviors within families than do the purely individualistic economic models. And, evolutionary insights help make sense of seemingly unstable preferences, behavioral anomalies, ${ }^{98}$ heuristic thought processes, ${ }^{99}$ and moral behaviors and judgments. ${ }^{100}$

ing: a Critical Appraisal or a Conversation Between two Academics in a Hotel Bar, in Ross Cranston and Anne Schick, eds, Law and Economics 105-11 (Australian National University 1982) (reforms make some tenants buy housing goods they do not want to buy); Daniel P. Schwallie, Note: The Implied Warranty of Habitability as a Mechanism for Redistributing Income: Good Goal, Bad Policy, 40 Case W Res L Rev 525 (1989-90) (law reform may hasten withdrawal of tenant quarters from the housing market); Ronald Coase, The Problem of Social Cost, 3 J L \& Econ 1 (1960) (initial allocation of rights may not matter to efficient allocation; and, negative externalities depend as much on the recipient as the source).

${ }_{98}$ These issues are discussed in Richard A. Epstein, Skepticism and Freedom, 141-43, 194-227 (Chicago 2003); Jones, Time-Shifted Rationality and the Law of Law's Leverage (cited in note 6).

${ }^{99}$ Jonathan Haidt, Rapporteur, Group Report: What Is the Role of Heuristics in Making Law?, in Gerd Gigerenzer \& Christopher Engel, eds, Heuristics and the Law 239, 241-43 (MIT 2006).

${ }^{100}$ See generally, Frans de Waal, Good Natured: The Origins of Right and Wrong in Humans and Other Animals (Harvard U Press, 1996); Jonathan Haidt \& Craig Joseph, 3 The Moral Mind in The Innate Mind, 367 (P. Carruthers, S. Laurence \& S. Stich, 
Because fitness maximization has fewer normative implications than does wealth maximization, as mentioned earlier, the possible legal policy implications of behavioral biology will very rarely seem as evident as they will for economics. On the other hand, behavioral biology may sometimes explain more usefully than economics why humans often behave in law-relevant ways that seem contrary to utility maximization (at least in the sense that law and economics scholars typically invoke the term).

Finally, because the historical political baggage that biology and economics contend with differs, the core criticisms of each of their intersections with law also differ. The economic focus on increasing total welfare (the size of the pie) at the expense of distributional concerns has led to accusations that when legal policymakers listen to economists the result is an exacerbation of the stratification of economic wealth. In contrast, biology must contend with having been misinvoked for, but nonetheless associated with, genocidal movements. Specifically, the genocidal activities of former Nazi Germany (themselves a reflection of eugenic policies openly adopted earlier in the United States ${ }^{101}$ ) have cast a long shadow over any attempt to use insights from biology for purposes that overlap in any way with governmental (and in this case legal) aims. ${ }^{102}$

Several additional, significant differences between law and economics and law and behavioral biology stem from differences in the age and maturity of the two subfields. Law and economics started as a movement several decades ago, ${ }^{103}$ and, as is common to more mature fields, law and economics has more readily available grant money, a variety of scholarly journals, ${ }^{104}$ and other accessories of interdisciplinary arenas that are both maturely developed and widely sub-

eds, Oxford 2007); Robinson, Kurzban, and Jones, The Origins of Shared Intuitions of Justice (cited in note 4); Owen D. Jones \& Robert Kurzban, Intuitions of Punishment, 77 Chi L Rev 1633 (2010). For discussion, see Walter Sinnott-Armstrong, ed, The Evolution of Morality: Adaptations and Innateness (MIT 2008).

${ }^{101}$ See generally Daniel J. Kevles, In the Name of Eugenics: Genetics and the Uses of Human Heredity (Knopf 1985); Elof Axel Carlson, The Unfit: A History of a Bad Idea (Cold Spring Harbor Laboratory 2001).

${ }^{102}$ For discussion of why behavioral biology offers no support for eugenic policies, see Jones \& Goldsmith, at 494-95 (cited in note 4).

${ }^{103}$ For a concise historical overview of law and economics, see Keith N. Hylton, Calabresi and the Intellectual History of Law and Economics, $64 \mathrm{Md} \mathrm{L}$ Rev 85 (2005).

${ }^{104}$ Journals include the Journal of Law and Economics; the Journal of Legal Studies; The American Law and Economics Review; The Supreme Court Economic Review; the Journal of Law, Economics and Organization; the International Review of Law and Economics; Review of Law and Economics; the European Journal of Law and Economics; Research in Law and Economics; Journal of Competition Law and Economics; Journal of International Economic Law; Antitrust Law and Economics Review; and The Economics of Legal Relationships. 
scribed ${ }^{105}$ Law and economics has benefitted not only from advocacy by the amazingly prolific writing of Richard Posner and others, but also from the entrepreneurial skills of Henry Manne and the economic clout of the Olin Foundation. Manne created highly successful retreats, informally dubbed "Pareto in the Pines," for law professors and judges, and has written about building law and economics as an institutional movement. ${ }^{106}$ Olin, for its part, sponsored law and economics programs around the country, providing scholars with both the time and incentives to do law and economics oriented work.

Early efforts in law and behavioral biology did not spread as quickly. However, continuing collaborations within and between the Gruter Institute for Law and Behavioral Research ${ }^{107}$ and the Society for Evolutionary Analysis in Law ${ }^{108}$ have sparked substantial, steady, and continuing scholarly interest, and increasing flows of grant money have begun to support developments in law and behavioral biology. 109

The field of law and behavioral biology is developing more slowly than did law and economics, and will probably continue to do so, because not only are there far more lawyers with economic training than with biology training (let alone training in behavioral biology), far more legal thinkers are trained in the social sciences than in the life sciences. Moreover, in law and economics, some of the foundational works were written by economists interested in law, while law tends to hold considerably less appeal for biologists. Last, many of the questions first raised by law and economics were low-hanging fruit; fields such as antitrust, securities, corporations, contracts, tax, and the regulation of explicit economic markets were all self-evident candidates for applying the economic microscope. ${ }^{110}$ And, unsurprisingly, the fields where law and economics is most fully developed remain those like antitrust, whereas economics has had less development and influence in other fields. On first glance, it would appear that there are fewer fields in law offering low-hanging fruit to biolo-

${ }^{105}$ At least 10 law and economics associations exist worldwide. See American Law and Economics Association website, online at http://www.amlecon.org/links.html (listing 9 other organizations).

${ }^{106}$ See, for example, Henry G. Manne, How Law and Economics was Marketed in a Hostile World: A Very Personal History, in Francesco Parisi, Charles K. Rowley, eds, The Origins of Law and Economics: Essays by the Founding Fathers 309 (Edward Elgar 2005).

${ }^{107}$ Gruter Institute for Law and Behavioral Research, online at http://www.gruter institute.org.

${ }^{108}$ Society for Evolutionary Analysis in Law, online at http://www.sealsite.org.

${ }^{109}$ For example, in 2007 the MacArthur Foundation initiated a $\$ 10,000,000$ project on Law and Neuroscience. See http://www.lawneuro.org.

${ }^{110}$ See Richard A. Posner, Economic Analysis of Law 23 (Aspen, 6th ed 2002). 
gists. Criminal law, family law, and torts come easily to mind, but beyond that, the applications of biology to law are often less direct than the applications of economics to law. ${ }^{111}$ Coase has argued that economics started as law and economics. ${ }^{112}$ Biology certainly did not start as law and biology.

\section{RECOMMENDATIONS}

To this point, we have surveyed the similarities and differences between biology and economics, and compared how law and behavioral biology, as a young interdisciplinary field, compares with the more established field of law and economics. Here, we offer a variety of recommendations for the future to existing and new scholars in both fields (particularly the younger field), as well as to those approaching law and biology scholarship from the outside.

1) The study of and knowledge about the influences of biological processes, including evolutionary, behavioral genetic, and neuroscientific ones, on human behavior has grown dramatically in recent decades. Prior debates about the extent of these influences on human behavior, particularly in the 1970s and 1980s, ${ }^{113}$ did little to stem the accelerating growth of the underlying scientific work. For example, evolutionary perspectives on human behavior have appeared with increasing frequency not only in biology, but also in anthropology, psychology, psychiatry, philosophy, sociology, political science, and medicine. ${ }^{114}$ And reference

${ }^{111}$ Thanks to Todd Zywicki for this point.

${ }^{112}$ Ronald Coase, Speech to First Annual Meeting of the American Law and Economics Association, May 25, 1991, University of Illinois at Urbana-Champaign.

${ }^{113}$ See, for example, The Sociobiology Debate: Reading on the Ethical and Scientific Issues Concerning Socbiobiology (Arthur L. Caplan, ed., 1978); Not in Our Genes, (cited in note 65).

${ }^{114}$ For just a small sampling, see Goldsmith \& Zimmerman (cited in note 46); Bobbi S. Low, Why Sex Matters: A Darwinian Look at Human Behavior (Princeton 2001); Lee Cronk, et al, eds, Adaptation and Human Behavior: An Anthropological Perspective (Aldine de Gruyter 2002); Peter J. Richerson \& Robert Boyd, Not By Genes Alone: How Culture Transformed Human Evolution (Chicago 2004); David Buss, Evolutionary Psychology: The New Science of the Mind (Allyn and Bacon, 3d ed 2007); David Buss, ed, The Handbook of Evolutionary Psychology (John Wiley \& Sons 2005); Robin Dunbar \& Louise Barrett, eds, Oxford Handbook of Evolutionary Psychology (Oxford 2007); Steven W. Gangestad \& Jeffrey A. Simpson, eds, The Evolution of Mind: Fundamental Questions and Controversies (Guilford 2007); Steven Pinker, The Blank Slate: The Modern Denial of Human Nature (Viking 2002); Michael McGuire \& Alfonso Troisi, Darwinian Psychiatry (Oxford 1998); Anthony Stevens \& John Price, Evolutionary Psychiatry: A New Beginning (Routledge 2000); Human 


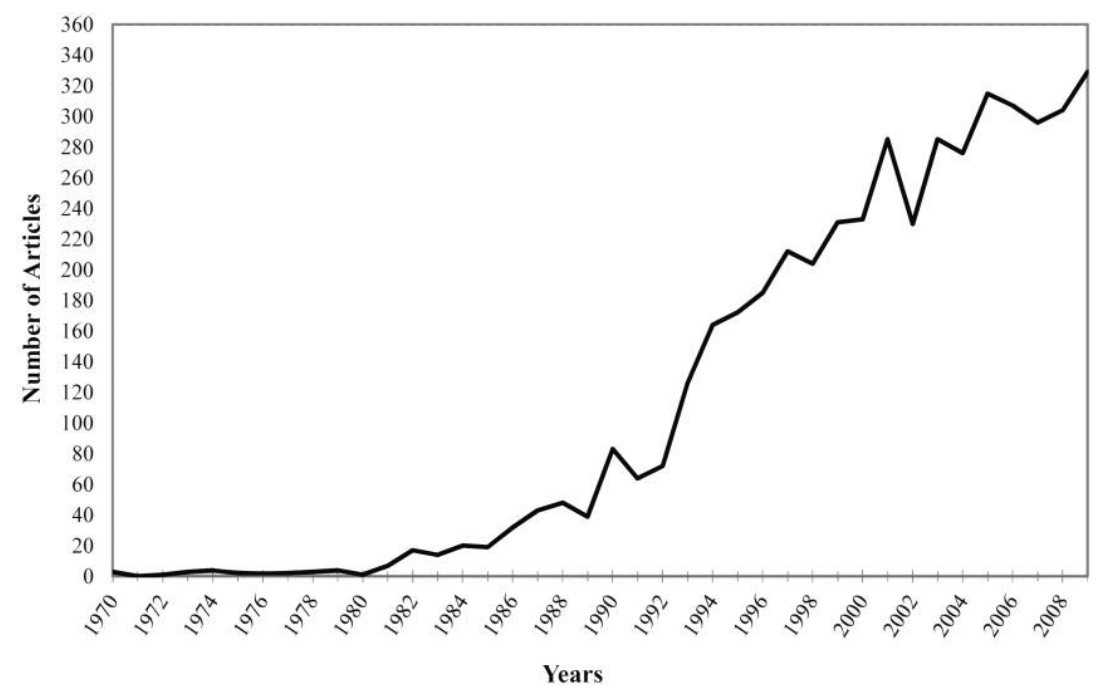

Figure 2. Articles in Westlaw "Journals \& Law Reviews" Database. Search term: dates(is[year]) and (evolution! /p biolog!) or (Darwin! /pb iolog!) or (evolution /s psychol!) or "evolutionary biology" or "evolutionary psychology" or sociobiology or "behavioral biology".

to and use of behavioral biology in legal scholarship has increased commensurately. ${ }^{115}$ (See Figure 2.) Consequently, it seems likely that behavioral biology perspectives on lawrelevant human behaviors will continue to be fruitful for research for a long time to come. And an investment in the field of law and behavioral biology can therefore yield substantial rewards.

2) Law and behavioral biology is not simply law and economics in another guise. The trajectories and implications of law and economics on one hand and law and behavioral biology on the other are not identical, despite a number of

Nature and Public Policy: An Evolutionary Approach (Palgrave Macmillan 2003); Albert Somit \& Steven A. Peterson, eds, Evolutionary Approaches in the Behavioral Sciences: Toward a Better Understanding of Human Nature (2001); Daniel Dennett, Darwin's Dangerous Idea: Evolution and the Meanings of Life (Simon \& Schuster 1995); Helena Cronin, The Ant and the Peacock: Altruism and Sexual Selection from Darwin to Today (Cambridge 1993); Jerome H. Barkow, Missing the Revolution: Darwinism for Social Scientists (Oxford 2005); Randolph M. Nesse \& George C. Williams, Why We Get Sick: The New Science of Darwinian Medicine (Vintage 1996); Wenda R. Trevathan, et al, Evolutionary Medicine (Oxford 1999).

${ }^{115}$ Indeed, the Society for Evolutionary Analysis in Law (S.E.A.L.) now has members spanning 32 countries. 
similarities. It would therefore be a mistake to assume that one should process or react to invocations of behavioral biology in law in the same way one processes or reacts to invocations of economics in law.

3) On the other hand, because the two subfields employ very similar tools, law and behavioral biology scholars should strive for better engagement with the law and economics literature, and vice versa. For example, both may benefit from attending conferences of the other, and from investing in basic training.

4) As with the law and economics literature, it would be a mistake to assume that analysts applying behavioral biology share a common purpose, a common (or any) political agenda, common methods, or common views on implications. Scholars exploring the possible uses of behavioral biology in law do so for a wide variety of different reasons, and come to this particular interdisciplinary intersection with diverse backgrounds, perspectives, and purposes. As is always the case, different people have different opinions about the implications or non-implications of biology to issues that matter to law. Those of us interested in the biology of behavior are diverse in views. The works of each scholar should be evaluated independently.

5) There is nothing inherently political about behavioral biology. ${ }^{116}$ As has by now often been said in this context, explanation is not justification, and description is not prescription. There is no way to reach a normative conclusion from processes or facts of biology without incorporating other values.

6) Nevertheless, it is probably safe to assume that some number of conservative scholars will-intentionally or otherwisedeploy arguments invoking behavioral biology in furtherance of various conservative agendas. ${ }^{117}$ Readers should (as with all scholarship) approach law and biology scholarship with a balance of skepticism and open-mindedness.

7) At the same time, the wide variety of scholars who have

${ }^{116}$ For more on this point, see Jones \& Goldsmith, at Part V (cited in note 4) (explaining why behavioral biology cannot legitimately be used to support political positions, including racism, sexism, social Darwinism (more properly "Social Spencerism"), eugenics, and the like).

${ }^{117}$ Some readers will, for example, assume that works such as the following could play into the hands of conservatives: Kingsley Browne, Sex and Temperament in Modern Society: A Darwinian View of the Glass Ceiling and the Gender Gap, 37 Ariz L Rev 971 (1995). 
written evolutionary analyses in law include those from across the political spectrum, from those who would selfidentify as conservatives to those who self-identify as liberals, feminists, or the like. So it is probably also safe to assume that some number of liberal scholars will-intentionally or otherwise-deploy arguments invoking behavioral biology in furtherance of various liberal agendas. ${ }^{118}$ Again, both skepticism and open-mindedness are appropriate.

8) There is a long history, to which we should closely attend, of biology being misused in furtherance of agendas inconsistent with legal equality between the sexes. It is entirely appropriate that this give us pause. But, to be clear, this recommends skepticism, rather than antagonism or reflexive rejection. For even if the differences between sexes that recur in biology make misuse a recurring problem, this is a situation in which the best defense to misuse is a deeper knowledge about, and continuing inquiry into, the effects of evolutionary processes on behavior generally, and the crucial interplay of genetic and environmental influences, specifically. In any event, the risks of harms from misuse should, if possible, be weighed on a case-by-case basis against the risks of forgone benefits from nonuse.

9) As was true for law and economics scholars, those scholars new to law and behavioral biology should take care to engage the primary literature on the topic, not just popular accounts, in efforts to avoid mistakes of over-simplification. It will often be useful to co-author or to vet manuscripts with biologists, evolutionists, and others with relevant training.

10) It is essential to understand behavioral biology if one is to critique it. Although this requires an investment in time, the fundamentals of the discipline are accessible to those willing to study it. Too often, critics who might have offered something constructive miss their mark by assuming to be true things (about behavioral biology, or the views of scholars mining it) that are not.

11) The influences of biological processes on human behavior are frequently controversial, frequently misunderstood, frequently misdescribed, and sometimes misapplied. This

${ }^{118}$ Some readers will, for example, assume that works such as the following could play into the hands of liberals: Katherine K. Baker, Biology for Feminists, 75 Chi-Kent L Rev 85 (2000). 
is, perhaps, inevitable. For one thing, the social sciences and the life sciences have proceeded on separate disciplinary tracks for generations. For another, although the influences of biological processes are increasingly understood, it is unlikely that they will ever be perfectly understood. After all, there are profound complexities inherent to a discipline that deals in genetically and developmentally unique organisms (in contrast to the case in physics, for example). Add in the challenges of trying to use insights from any technical discipline in an area as subtle as law-particularly one that has sometimes been misused in the past-and discussions quickly get complicated.

12) Those interested in law and behavior may find it useful to stay informed of developments in the area. A good way to do this is to join S.E.A.L.- the Society for Evolutionary Analysis in Law (www.sealsite.org). Not only does the organization help distribute information about recent scholarship, it also hosts annual scholarship conferences at which to present and discuss ideas.

13) When generating research ideas, law and behavioral biology scholars should strive for consilience ${ }^{119}$ by weaving together insights from biology and economics that come from their common tools. Not only is consilience an important end in itself, for the increased usefulness that decreased inconsistencies can bring, but this exercise can also frame behavioral biology discussions more accessibly for readers.

14) While there are numerous overlaps between economics and biology, behavioral biology has much to contribute on its own terms. Scholars should identify those places where behavioral biology adds insights that economics failed to identify. Research ideas might include (but are by no means limited to) insights into preferences and insights into so-called "sticky" (change-resistant) behaviors, in particular those often evident in the contexts of family law, sexuality and reproduction, and criminal law.

15) As law and economics scholars recognized, an understanding of tradeoffs, including opportunity costs, is important. Any comprehensive theory of human behavior must acknowl-

${ }_{119}$ As described by E.O. Wilson, who revived this under-used term, consilience is "the linking of fact and fact-based theory across disciplines to create a common groundwork of explanation." Edward O. Wilson, Consilience: The Unity of Knowledge 8 (Knopf 1998). 
edge and incorporate competing conceptual ideas. In economics, for example, actors face a tradeoff between their preferences for consumption and leisure, and, as a result of that tradeoff, most humans engage in some but limited leisure. In the context of behavioral biology, evolutionary predispositions lend insights into human behavior, but so does the amazing plasticity of the brain (and the behavioral plasticity it is capable of generating). Similarly, although it might be useful to model humans as agents striving to maximize both their inclusive fitness and their material resources, they also ultimately confront tradeoffs between the two. Moreover, the attainment of either is sometimes subject to constraints generated by a need to survive within one's social group (i.e., avoid ostracism). Much interesting work can be generated by exploring these tradeoffs, and their implications for legal policy.

16) Law and behavioral biology should avoid the imperialistic aspirations that plagued some early law and economics scholars. No one field possesses a monopoly on valuable insights regarding human behavior. Instead, important insights into behavior often result from combining insights from multiple fields (as Darwin, Friedman, Alchian, Trivers, and Maynard Smith did).

17) Similarly, law and behavioral biology scholars should avoid overclaiming the extent to which its tools are useful to law. No field can answer all questions of legal policy, and the success of the discipline could turn on avoiding the implausible and, ideally, beginning with clear applications.

18) Finally, because the low-hanging fruit in law and economics has all been plucked, there are significant opportunities in law and behavioral biology with potentially greater returns for scholars already familiar with law and economics. There are enormously expansive territories in law and behavioral biology that remain unexplored, with the consequence that law and behavioral biology is growing and accelerating. The extent of useful work yet to be done vastly exceeds the work that already has been done. There are opportunities, here, for people with the commitment and interest to explore entire subfields of law (such as torts, family law, and criminal law) through the lens of behavioral biology. Along the way, scholars in law and behavioral biology can borrow from the economic methodologies that already have been translated into the legal literature. In tackling law and 
behavioral biology, the law and economics scholars therefore will often enjoy a competitive advantage.

\section{CON CLUSION}

This article has provided a very brief overview of the similarities and differences between economics and behavioral biology, as well as between the related intersections of law and economics on one hand, and law and behavioral biology on the other. To the question with which we opened (might law and biology be the next law and economics?) we offer an unequivocal yes and no. We have identified important overlaps, as well as important differences-both in the substance of the disciplines themselves and also in the pathways for incorporation into legal thinking.

We believe that the overlaps between economics and biology warrant even greater congress between these two disciplines, and expanded exchange between the legal thinkers interested in each of them. We also believe that the differences between economics and biology warrant individualized attention to each, particularly to the comparatively under-explored ways in which the influence of biological processes on human brains and behaviors are relevant to achieving, as efficiently and effectively as feasible, the goals society assigns to law. 